\title{
Nutrient metabolism, mass balance, and microbial structure community in a novel denitrifying phosphorus removal system based on the utilizing rules of acetate and propionate
}

\author{
Miao Zhanga ${ }^{\mathrm{a}}$, Chenjie Zhu ${ }^{\mathrm{a}}$, Ting Pan ${ }^{\mathrm{a}}$, Yajun Fan ${ }^{\mathrm{b}}$, Ana Soares ${ }^{\mathrm{c}}$, Jun Wu $\mathbf{u}^{\mathrm{a}}$, Chengda He $\mathrm{a}^{\text {* }}$ \\ ${ }^{a}$ College of Environmental Science and Engineering, Yangzhou University, Yangzhou 225127, PR China \\ ${ }^{\mathrm{b}}$ Yangzhou Polytechnic Institute, Yangzhou 225127, PR China \\ ${ }^{\mathrm{c}}$ Water Sciences Institute, Cranfield University, Cranfield, MK 43 OAL, UK
}

*Corresponding author: Chengda He, College of Environmental Science and Engineering, Yangzhou University, Yangzhou 225127, PR China

E-mail address: hcd@yzu.edu.cn

\begin{abstract}
The effect of acetate (HAc) and propionate (HPr) on denitrifying phosphorus removal (DPR) was evaluated in a novel two-sludge $\mathrm{A}^{2} / \mathrm{O}$ - MBBR (anaerobic/anoxic/oxic - moving bed biofilm reactor) system. Results showed that it was the carbon source transformation and utilization especially the composition of poly- $\beta$-hydroxyalkanoates (PHA) (mainly poly- $\beta$ hydroxybutyrate (PHB) and poly-bhydroxyvalerate (PHV)) decided DPR performance, where the the co-exist of HAc and HPr promoted the optimal nitrogen (85.77\%) and phosphorus (91.37\%) removals. It facilitated the balance of PHB and PHV and removing $1 \mathrm{mg} \mathrm{NO}_{3}{ }^{-}\left(\mathrm{PO}_{4}{ }^{3-}\right)$ consumed 3.04 - 4.25 (6.84 - 9.82) mgPHA, where approximately 40 - 45\% carbon source was saved. Mass balance revealed the main metabolic pathways of carbon $\left(\mathrm{M}_{\mathrm{An}, \mathrm{C}}\right.$ (consumed amount in anaerobic stage) and $\mathrm{M}_{\mathrm{A}-\mathrm{O}, \mathrm{C}}\left(\right.$ consumed amount in anoxic and oxic stages): 66.38 - 76.19\%), nitrogen ( $\mathrm{M}_{\mathrm{DPR}, \mathrm{N}}($ consumed amount in DPR): 57.01 65.75\%), and phosphorus ( $\mathrm{M}_{\mathrm{WS}, \mathrm{P}}$ (discharged amount in waste sludge): $\left.81.05-85.82 \%\right)$. Furthermore, the relative abundance
\end{abstract}


and microbial distribution were assessed to elucidate DPR mechanism (e.g. Accumulibacter, Acinetobacter, Dechloromonas, Competibacter, and Defluviicoccus) in the $\mathrm{A}^{2} / \mathrm{O}$ reactor and nitrification performance (e.g. Nitrosomonas, Nitrosomonadaceae and Nitrospira) in the MBBR. Carbon source was demonstrated as the key point to stimulate the biodiversity and bioactivity related to DPR potential, and the operational strategy of carbon source addition was proposed based on the utilizing rules of HAc and HPr.

Keywords: $A^{2} / \mathrm{O}$ - MBBR; carbon source; denitrifying phosphorus removal; mass balance; Illumina MiSeq sequencing; operation optimization 


\section{Nomenclature}

$\mathrm{C} / \mathrm{N}$ : the ratio of $\mathrm{COD}$ to $\mathrm{TN}$

HAc, HPr: acetate, propionate

WWTPs: wastewater treatment plants

BNR: biological nutrient removal

DPR: denitrifying phosphorus removal

PAOs (DPAOs): phosphorus accumulation organisms (denitrifying PAOs)

GAOs (DGAOs): glycogen accumulating organisms (denitrifying GAOs)

AOB, NOB, OHOs: ammonia-oxidizing bacteria, nitrite-oxidizing bacteria, ordinary heterotrophic organisms

$\mathrm{A}^{2} / \mathrm{O}$ - MBBR: anaerobic/anoxic/oxic - moving bed biofilm reactor

VFAs: volatile fatty acids; $\mathrm{mg} / \mathrm{L}$

PHA, PHB, PHV: poly- $\beta$-hydroxyalkanoates, poly- $\beta$-hydroxybutyrate, poly-bhydroxyvalerate; mgCOD/L

Gly: glycogen; mgCOD/L

MLSS, VSS: mixed liquor suspended solids, volatile suspended solids; mg/L

SND: simultaneous nitrification and denitrification

$\mathrm{M}_{\text {inf,C: }}$ COD amount in influent; $\mathrm{mg} / \mathrm{d}$

$\mathrm{M}_{\mathrm{An}, \mathrm{C}}$ : COD consumed amount in anaerobic stage; $\mathrm{mg} / \mathrm{d}$

$\mathrm{M}_{\mathrm{A}-\mathrm{O}, \mathrm{C}}$ : COD consumed amount in anoxic and oxic stages; $\mathrm{mg} / \mathrm{d}$

$\mathrm{M}_{\mathrm{MBBR}, \mathrm{C}}$ : COD consumed amount in MBBR; mg/d

Mws,C: COD discharged amount in waste sludge; mg/d

$\mathrm{M}_{\text {eff,c: }}$ COD residual amount in effluent; $\mathrm{mg} / \mathrm{d}$

$\mathrm{M}_{\text {inf,N: }} \mathrm{TN}$ amount in influent; $\mathrm{mg} / \mathrm{d}$

$M_{\text {DPR,N }}$ TN consumed amount in DPR; mg/d

$\mathrm{M}_{\text {Assi,N }}$ : TN consumed amount in microbial assimilation; $\mathrm{mg} / \mathrm{d}$

MSND,N: TN consumed amount in SND; mg/d

Meff,N: TN residual amount in effluent; $\mathrm{mg} / \mathrm{d}$

$\mathrm{M}_{\text {inf,P: }} \mathrm{PO}_{4}{ }^{3-}$ amount in influent; $\mathrm{mg} / \mathrm{d}$

MwS,P: $\mathrm{PO}_{4}{ }^{3-}$ discharged amount in waste sludge; $\mathrm{mg} / \mathrm{d}$

Meff,P: $\mathrm{PO}_{4}{ }^{3-}$ residual amount in effluent; $\mathrm{mg} / \mathrm{d}$

$\mathrm{TP}_{\text {An: }} \mathrm{PO}_{4}{ }^{3-}$ release amount in anaerobic stage; $\mathrm{mg} / \mathrm{L}$

$\mathrm{COD}_{\text {An: }}$ COD amount in anaerobic effluent; $\mathrm{mg} / \mathrm{L}$

$\mathrm{COD}_{\mathrm{A} 2 / \mathrm{O}}$ : COD amount in $\mathrm{A}^{2} / \mathrm{O}$ effluent; $\mathrm{mg} / \mathrm{L}$

CODeff: COD amount in final effluent; $\mathrm{mg} / \mathrm{L}$

$\triangle$ COD: COD variation; $\mathrm{mg} / \mathrm{L}$

EBPR: enhanced biological P removal

OTUs: operational taxonomic units 


\section{Introduction}

Nitrogen $(\mathrm{N})$ and phosphorus $(\mathrm{P})$ mainly responsible for eutrophication have become the focus of increased attention, and many regulations have been made to meet the strict nutrient discharge standards (Brown et al., 2011). Carbon (C)/N ratio (refers to chemical oxygen demand (COD)/total nitrogen $(\mathrm{TN})$ ) as a crucial parameter directly affects denitrification, $\mathrm{P}$ removal, and microbial growth (Peng \& Ge, 2011). Generally, external carbon sources (e.g. acetate (HAc) and propionate $(\mathrm{HPr})$ ) are added to alleviate the substrate metabolism and microbial competition between $\mathrm{N}$ and $\mathrm{P}$ removals in wastewater treatment plants (WWTPs) especially for low C/N ratio sewage (lower than 4) (Zhang et al., 2019a). Thus, the advanced N and P removals without increasing carbon source addition and energy consumption remains a challenge in traditional biological nutrient removal (BNR) systems (Wang et al., 2019a).

Denitrifying phosphorus removal (DPR) has been a research hotspot due to N and P removals simultaneously through the same carbon source, and phosphorus accumulation organisms (PAOs) especially denitrifying PAOs (DPAOs) can be enriched using nitrate $\left(\mathrm{NO}_{3}^{-}\right)$or nitrite $\left(\mathrm{NO}_{2}^{-}\right)$as electron acceptors instead of oxygen $\left(\mathrm{O}_{2}\right)$, resulting in considerable aeration lowering, carbon sources saving as well as sludge reducing (Ahn et al., 2002; Kuba et al., 1996). Particularly, the shift of operation mode from single-sludge to two-sludge was adopted to maximize the utilization of existing carbon sources (Zhang et al., 2016c; Zhang et al., 2013; Zhao et al., 2016a). Two-sludge systems could create favorable environment for heterotrophic PAOs or DPAOs in anaerobic-anoxic sludge and autotrophic nitrifiers in oxic biofilm (Chen et al., 2011). With the separation of sludge retention time (SRT), it successfully solved the adverse conditions of long aeration required for efficient nitrification in single-sludge systems (Marcelino et al., 2011), especially for high-strength ammonia sewage treatment under low temperature (Zhang et al., 2019b). However, glycogen accumulating organisms (GAOs) and denitrifying GAOs (DGAOs) competed with PAOs and DPAOs without contributing to P removal (Oehmen et al., 2007). On the other hand, other groups known as ammonia-oxidizing bacteria (AOB) and nitrite-oxidizing bacteria (NOB) also have contradiction with ordinary heterotrophic organisms (OHOs) (Wang et al., 2019b) in N removal. To improve nutrient metabolism efficiency, it is necessary to understand and control the competition among these microorganisms. 
Actually, the micro competition can be influenced by many macro factors, such as temperature, $\mathrm{pH}$, hydraulic retention time, electron acceptor, $\mathrm{C} / \mathrm{N}$ ratio, carbon source especially the COD composition of the wastewater (Chen et al., 2015; Filipe et al., 2001; Yang et al., 2018; Zhang et al., 2016a). As the most common carbon sources, HAc and HPr accounted for 60 $80 \%$ and have been widely studied since they are the abundant volatile fatty acid (VFA) compositions in wastewater (Cai et al., 2016; Wang et al., 2010). But the effects of HAc and HPr on microbial competition and DPR performance were not always consistent, as successful and deteriorative DPR systems in the presence of HAc and HPr have both been reported in the literatures (Carvalheira et al., 2014; Oehmen et al., 2006; Pijuan et al., 2009). Due to this limitation, the nutrient metabolism has not yet been clarified clearly in most DPR systems, even though it represents a common goal to enrich and maximize PAOs and DPAOs (Carvalheira et al., 2014). Moreover, there is limited knowledge about how C, N, and P evolve, mostly because of the fact that so many combined factors take part in nutrient metabolism.

These provided the motivation for the present study, which investigated the single-factor effect of carbon source on nutrient metabolism, mass balance, and microbial evolution based on a two-sludge $\mathrm{A}^{2} / \mathrm{O}$ - MBBR (anaerobic/anoxic/oxic moving bed biofilm reactor) system (Zhang et al., 2019b), in order to 1) describe its impact on the overall performance of C, $\mathrm{N}$, and P, particularly with regards to the link between intercellular carbon source (e.g. poly- $\beta$-hydroxyalkanoates (PHA) and glycogen (Gly)) and nutrient metabolic mechanism, 2) evaluate its impact on the evolutions of $\mathrm{C}, \mathrm{N}$, and $\mathrm{P}$, where significant differences obtained from mass balance provided a new perspective on the transition from nutrient removal into energy conservation and resource recovery in wastewater treatment, and 3) understand its impact on microbial community of biological diversity and functional bacteria abundance for high-efficient utilization of carbon source.

\section{Materials and methods}

\subsection{Wastewater quality and seed sludge}

The wastewater was artificially synthesized with $250 \pm 20 \mathrm{mg} / \mathrm{L} \mathrm{COD}$ (provided by HAc and HPr), $65 \pm 5 \mathrm{mg} / \mathrm{L} \mathrm{NH}_{4}{ }^{+}$ (provided by $\mathrm{NH}_{4} \mathrm{Cl}$ ), $6 \pm 0.50 \mathrm{mg} / \mathrm{L} \mathrm{PO}_{4}{ }^{3-}$ (provided by $\mathrm{KH}_{2} \mathrm{PO}_{4}$ ). Meanwhile, trace element was added to the synthetic wastewater (g/L) (Zhang et al., 2019a): $\mathrm{MgSO}_{4} \cdot 7 \mathrm{H}_{2} \mathrm{O}, 0.88 ; \mathrm{FeCl}_{3} \cdot 6 \mathrm{H}_{2} \mathrm{O}, 1.50 ; \mathrm{Na}_{2} \mathrm{MoO}_{4}, 0.06 ; \mathrm{ZnSO}_{4} \cdot 2 \mathrm{H}_{2} \mathrm{O}, 0.12 ; \mathrm{CuSO}_{4}$, 
0.03; $\mathrm{CoCl}_{2} \cdot 6 \mathrm{H}_{2} \mathrm{O}, 0.15 ; \mathrm{CaCl}_{2} \cdot 2 \mathrm{H}_{2} \mathrm{O}, 1.40 ; \mathrm{KI}, 0.18 ; \mathrm{H}_{3} \mathrm{BO}_{3}, 0.15 ;$ and $\mathrm{C}_{10} \mathrm{H}_{16} \mathrm{~N}_{2} \mathrm{O}_{8}, 10$. The average influent $\mathrm{C} / \mathrm{N}$ and $\mathrm{C} / \mathrm{P}$ ratios were $3.85 \pm 0.15$ and $41.67 \pm 1.60$, respectively, where $\mathrm{pH}$ was controlled at $7 \pm 0.50$ by adding $\mathrm{Na}_{2} \mathrm{CO}_{3}(1 \mathrm{M})$ to maintain biological stability.

$\mathrm{A}^{2} / \mathrm{O}$ reactor sludge was inoculated from the CAST process in Tangwang WWTPs (Yangzhou, China), and the mixed liquor suspended solids (MLSS) and volatile suspended solids (VSS) was around $6000 \mathrm{mg} / \mathrm{L}$ and $4500 \mathrm{mg} / \mathrm{L}$ with better settling properties (sludge volume index (SVI): 140 - $180 \mathrm{~mL} / \mathrm{gVSS}$ ) (Zhang et al., 2020) and stable $\mathrm{N}$ and $\mathrm{P}$ removal performances. Based on the $\mathrm{A}^{2} / \mathrm{O}$ effluent with a large amount of $\mathrm{NH}_{4}{ }^{+}$, MBBR achieved the quick natural biofilm formation within 18 days without additional inoculation sludge (Zhang et al., 2019b).

\section{$2.2 \mathrm{~A}^{2} / \mathrm{O}$ - MBBR system and experimental operation}

The $\mathrm{A}^{2} / \mathrm{O}$ - MBBR system was mainly made up of feeding tank, $\mathrm{A}^{2} / \mathrm{O}$ reactor, middle settler, MBBR reactor (including settling zone), and effluent tank (Fig.S1). The feeding tank (working volume: $150 \mathrm{~L}$ ) was used to provide raw water, and the $\mathrm{A}^{2} / \mathrm{O}$ reactor (working volume: $28 \mathrm{~L}$ ) was evenly divided into eight chambers including anaerobic zones $\left(\mathrm{A}_{\mathrm{n} 1}, \mathrm{~A}_{\mathrm{n} 2}\right)$, anoxic zones $\left(\mathrm{A}_{1}-\mathrm{A}_{5}\right)$ and oxic zone $(\mathrm{O})$ with the volume ratio of 2:5:1. The influent flow rate $(\mathrm{Q})$ was controlled at $67.20 \mathrm{~L} / \mathrm{d}$, and the hydraulic retention time (HRT) was $10 \mathrm{~h}$ to strengthen DPR due to longer anaerobic/anoxic reaction $(8.75 \mathrm{~h})$. The dissolved oxygen (DO) in the short oxic zone was maintained at $1.50 \pm 0.50 \mathrm{mg} / \mathrm{L}$ to expel nitrogen gas generated by DPR and absorb the remaining $\mathrm{PO}_{4}{ }^{3-}$. The $\mathrm{A}^{2} / \mathrm{O}$ effluent flowed into the middle settler for the sludge and water separation, where partial settled sludge was recycled (sludge return ratio: $r=100 \%)$ to the anaerobic zone of the $A^{2} / O$ reactor $\left(A_{n 1}\right)$ and the supernatant entered into the following MBBR (working volume: $10.50 \mathrm{~L})$. Specially, the $\mathrm{A}^{2} / \mathrm{O}$ reactor was controlled at a shorter SRT $(10 \pm 2 \mathrm{~d})$ by discharging wasted sludge.

The MBBR composed of three identical chambers $\left(\mathrm{N}_{1}, \mathrm{~N}_{2}\right.$ and $\left.\mathrm{N}_{3}\right)$ was operated at a longer SRT $(80 \pm 2$ d) (Zhang et al., 2019b) for nitrification. It was packed with cylinder polypropylene carriers (size: $5 \mathrm{~mm} \times 3 \mathrm{~mm}$; density: $960-1000$ $\mathrm{kg} / \mathrm{m}^{3}$; effective porosity: $98 \%$; specific surface area: $1500 \mathrm{~m}^{2} / \mathrm{m}^{3}$ ) with the filling ratio of $50 \pm 5 \%$. All carriers can move and circulate by controlling DO of $3.50-4.50 \mathrm{mg} / \mathrm{L}$ to enhance the mass transfer and diffusion efficiency (Manser, 2005). The 
settling zone was set to collect detached biofilm so as to prevent nitrifiers entering the $\mathrm{A}^{2} / \mathrm{O}$ reactor, and the nitrate acting as electron acceptor for DPR was recycled (nitrate recycle ratio: $R=400 \%$ ) to the anoxic zone of the $A^{2} / O$ reactor $\left(A_{1}\right)$.

The system lasted 120 days divided into three phases by changing carbon source types (Phase 1: HAc; Phase 2: 0.5 HAc + 0.5 HPr; Phase 3: HPr) $(\mathrm{COD}=250 \pm 20 \mathrm{mg} / \mathrm{L})$ (Table 1). Particularly, each phase kept running for 40 days (> 3SRTs) under similar operation parameters to ensure the stable operation and data reliability (Zhang et al., 2016a). The influent belonged to typical low $\mathrm{C} / \mathrm{N}$ ratio $(3.85 \pm 0.15)$ wastewater, $\mathrm{HRT}$ and average $\mathrm{VSS}$ of the $\mathrm{A}^{2} / \mathrm{O}$ reactor was $10 \mathrm{~h}, 4000 \mathrm{mg} / \mathrm{L}$ with the volume ratio of 2:5:1, sludge recycling and nitrate recycling were set as $100 \%$ and $400 \%$ at ambient temperature of $22 \pm 3^{\circ} \mathrm{C}$. At the end of each phase (Day 40,80,120), mass balance, nutrient metabolism and microbial community analysis were conducted.

\subsection{Analysis methods}

COD was monitored using a COD quick-analysis apparatus (LH-3C, Lanzhou, China), nitrogen (including $\mathrm{NH}_{4}{ }^{+}, \mathrm{NO}_{3}{ }^{-}$ and $\mathrm{NO}_{2}^{-}$), $\mathrm{PO}_{4}^{3-}$, MLSS and VSS were analyzed based on the standard methods (AWWA, 2005). TN was measured with a TN/TOC analyzer (MultiN/C3100, Analytik Jena, AG). VFA and PHA (including poly- $\beta$-hydroxybutyrate (PHB), polybhydroxyvalerate (PHV) and negligible poly-3-hydroxy-2-methylvalerate (PH2MV) (Zhang et al., 2019a)) were detected using the gas chromatograph (Agilent 6890N) with Agilent DB - 1 column (Oehmen et al., 2010), while Gly was extracted and analyzed using the Anthrone method. Temperature, $\mathrm{pH}$ and DO were monitored using a WTW pH/DO meter (WTW Multi 340i, Germany).

\subsection{Calculation}

\subsubsection{Carbon balance analysis}

The total amount of carbon entered into the system $\left(\mathrm{M}_{\mathrm{inf}, \mathrm{C}}\right)$ mainly included the following aspects: COD consumed amount in anaerobic stage $\left(\mathrm{M}_{\mathrm{An}, \mathrm{C}}\right)$, anoxic and oxic stages $\left(\mathrm{M}_{\mathrm{A}-\mathrm{O}, \mathrm{C}}\right)$ during the $\mathrm{A}^{2} / \mathrm{O}$ reactor, oxidation amount in the $\mathrm{MBBR}\left(\mathrm{M}_{\mathrm{MBBR}, \mathrm{C}}\right)$, discharge amount of waste sludge $\left(\mathrm{M}_{\mathrm{WS}, \mathrm{C}}\right)$, and residual amount in the effluent $\left(\mathrm{M}_{\mathrm{eff}, \mathrm{C}}\right)$, where the carbon balance ratio $\left(\mathrm{R}_{\mathrm{C}}\right)$ can be finally analyzed according to the equations below: 


$$
\begin{aligned}
& \mathrm{M}_{\mathrm{inf}, \mathrm{C}}=\mathrm{Q}_{\mathrm{inf}} \cdot \mathrm{C}_{\mathrm{inf}} \\
& \mathrm{M}_{\mathrm{An}, \mathrm{C}}=\mathrm{Q}_{\text {inf }} \cdot \mathrm{C}_{\mathrm{inf}}+\mathrm{r} \cdot \mathrm{Q}_{\mathrm{inf}} \cdot \mathrm{C}_{\mathrm{RS}}-(1+\mathrm{r}) \cdot \mathrm{Q}_{\text {inf }} \cdot \mathrm{C}_{\mathrm{An}} \\
& M_{A-O, C}=(1+r) Q_{\text {inf }} \cdot C_{A n}+R \cdot Q_{\text {inf }} \cdot C_{\text {eff }}-(1+r+R) \cdot Q_{\text {inf }} \cdot C_{O} \\
& M_{M B B R, C}=(1+R) \cdot Q_{\text {inf }} \cdot C_{M S}-R \cdot Q_{\text {inf }} \cdot C_{\text {eff }}-Q_{\text {eff }} \cdot C_{\text {eff }} \\
& \mathrm{Mws}, \mathrm{C}_{\mathrm{W}}=\mathrm{Qws}_{\mathrm{w}} \cdot \mathrm{X}_{\mathrm{ws}} \cdot f_{\mathrm{Cv}} \cdot f \\
& \mathrm{M}_{\mathrm{eff}, \mathrm{C}}=\mathrm{Q}_{\mathrm{eff}} \cdot \mathrm{C}_{\mathrm{eff}} \\
& \mathrm{R}_{\mathrm{C}}=\left(\mathrm{M}_{\mathrm{An}, \mathrm{C}}+\mathrm{M}_{\mathrm{A}-\mathrm{O}, \mathrm{C}}+\mathrm{M}_{\mathrm{MBBR}, \mathrm{C}}+\mathrm{M}_{\mathrm{WS}, \mathrm{C}}+\mathrm{M}_{\mathrm{eff}, \mathrm{C}}\right) / \mathrm{M}_{\mathrm{inf}, \mathrm{C}} \cdot 100 \%
\end{aligned}
$$

Where $Q_{\text {inf }}, Q_{w s}, Q_{\text {eff }}$ were the flow rates of influent, waste sludge, and effluent ( $Q_{\text {inf }}=Q_{\text {eff }}$ ), L/d; $C_{\text {inf }}, C_{R S}, C_{A n}, C_{O}, C_{M S}, C_{\text {eff }}$ were the COD concentrations of influent, recycled sludge, anaerobic stage, oxic stage, middle settler $\left(\mathrm{C}_{\mathrm{MS}}=\mathrm{C}_{\mathrm{RS}}\right)$, and effluent, respectively, $\mathrm{mg} / \mathrm{L} ; r$, sludge return ratio, $100 \% ; R$, nitrate recycle ratio, $400 \% ; X_{\text {WS }}$ was VSS concentration in waste sludge, $\mathrm{mg} / \mathrm{L} ; f$ was the ratio of VSS/MLSS; $f_{\mathrm{CV}}$ was COD stoichiometric coefficient in activated sludge, $1.48 \mathrm{mgCOD} / \mathrm{mgVSS}$ (Chuang \& Ouyang, 2000).

\subsubsection{Nitrogen balance analysis}

The total amount of nitrogen in the system $\left(\mathrm{M}_{\mathrm{inf}, \mathrm{N}}\right)$ was mainly composed of four parts: TN removal amount in DPR $\left(\mathrm{M}_{\mathrm{DPR}, \mathrm{N}}\right)$ and microbial assimilation $\left(\mathrm{M}_{\mathrm{Assi}, \mathrm{N}}\right)$, simultaneous nitrification and denitrification (SND) in the $\mathrm{MBBR}\left(\mathrm{M}_{\mathrm{SND}, \mathrm{N}}\right)$ and residual amount in the effluent $\left(\mathrm{M}_{\mathrm{effi}, \mathrm{N}}\right)(\mathrm{Chen}$ et al., 2014; Lee et al., 2008).

$$
\begin{aligned}
& M_{\text {inf }, \mathrm{N}}=Q_{\text {inf }} \cdot N_{\text {inf }} \\
& M_{D P R, N}=\left(N_{A, \text { inf }}-N_{A, \text { eff }}\right)(1+R+r) \\
& M_{\text {Assi,N }}=Q_{\text {ws }} \cdot X_{W S} \cdot f \cdot f_{\mathrm{N} / \text { biomass }} \\
& M_{\text {eff,N }}=Q_{\text {eff }} \cdot N_{\text {eff }} \\
& M_{S N D, N}=M_{\text {inf,N }}-M_{D P R, N}-M_{\text {Assi,N }}-M_{\text {eff,N }}
\end{aligned}
$$

Where $\mathrm{N}_{\text {inf }}, \mathrm{N}_{\mathrm{eff}}, \mathrm{N}_{\mathrm{A}, \text { inf }}, \mathrm{N}_{\mathrm{A}, \text { eff }}$ Were the TN concentrations of influent, effluent, and anoxic influent, effluent, respectively, mg/L; $f_{\mathrm{N} / \text { biomass }}$ was nitrogen content in activated sludge, $12.39 \%$ (Henze et al., 1999). 


\subsubsection{Phosphorus balance analysis}

The total amount of phosphorus in the system $\left(\mathrm{M}_{\mathrm{inf}, \mathrm{P}}\right)$ was mainly removed through the discharge of waste sludge $\left(\mathrm{M}_{\mathrm{WS}, \mathrm{P}}\right)$, but the residual amount in the effluent $\left(\mathrm{M}_{\mathrm{eff}, \mathrm{P}}\right)$ indirectly determined the phosphorus balance ratio $\left(\mathrm{R}_{\mathrm{P}}\right)$.

$$
\begin{gathered}
M_{\text {inf,P }}=Q_{\text {inf }} \cdot P_{\text {inf }} \\
M_{W S, P}=Q_{w s} \cdot X_{W S} \cdot f_{P} \\
M_{\text {eff }, P}=Q_{\text {eff }} \cdot P_{\text {eff }} \\
R_{P}=\left(M_{w S, P}+M_{\text {eff,P }}\right) / M_{\text {inf,P }} \cdot 100 \%
\end{gathered}
$$

Where $\mathrm{P}$ inf, $\mathrm{P}_{\text {eff, }}$ were the $\mathrm{PO}_{4}{ }^{3-}$ concentrations of influent and effluent, $\mathrm{mg} / \mathrm{L} ; f_{\mathrm{P}}$ was phosphorus content in activated sludge, $1.50-2.50 \%$ (Henze et al., 1999).

\subsection{Microbial community analysis}

The seed sludge (Day 0), $\mathrm{A}^{2} / \mathrm{O}$ sludges (Day 40, 80, and 120) and nitrification biofilms of MBBR $\left(\mathrm{N}_{1}, \mathrm{~N}_{2}\right.$ and $\mathrm{N}_{3}$, Day 120) (Table 1) were collected for Illumina MiSeq sequencing analysis (Rollemberg et al., 2019) through Shanghai MEIJI Biotechnology (PE300 platform, Personalbio Biotechnology Co., Ltd., Shanghai, China). Genomic DNA was extracted using the E.Z.N.A. ( ${ }^{\circledR}$ Soil DNA Kit (Omega Bio-tek, Norcross, GA, USA), and the average OD260/280 value of all samples was $1.96 \pm 0.02$. $16 \mathrm{~S}$ rRNA gene polymerase chain reaction $(\mathrm{PCR})$ amplification was performed on the $\mathrm{ABI}$ GeneAmp ${ }^{\circledR} 9700$ PCR System. The primer sequences of V3-V4 region ( 392 bp) used in this study were as follows: 338F (5'ACTCCTACGGGAGGCAGCA-3') and 806R (5'-GGACTACHVGGGTWTCTAAT-3'). The pyrosequencing procedure, statistical and bioinformatics analysis (Accession number: SRP223205) were conducted following the previous description (Zhang et al., 2019a).

\section{Results and discussions}

\subsection{Effect of carbon source on the overall performance}

The influent COD varied from 230.20 to $269.30 \mathrm{mg} / \mathrm{L}$ and was mainly utilized in the anaerobic zones. In Phase 1 , the average anaerobic effluent $\left(\mathrm{COD}_{\mathrm{An}}\right)$ was $98.13 \mathrm{mg} / \mathrm{L}$ using HAc as sole carbon source (Fig.1A). According to Eq. (1-2), $\mathrm{M}_{\mathrm{An}, \mathrm{C}}$ 
was $157.38 \mathrm{mg} / \mathrm{L}$ and the $\mathrm{M}_{\mathrm{An}, \mathrm{C}}$ efficiency only reached to $68.78 \%$, leading to poor anaerobic $\mathrm{P}$ release $\left(\mathrm{TP}_{\mathrm{An}}=15.27 \mathrm{mg} / \mathrm{L}\right)$

(Fig.1C). Anoxic DPR efficiency achieved to $87.54 \%$ with the TN removal of $78.70 \%$ (Fig.1B), and the average effluent TN was $13.58 \mathrm{mg} / \mathrm{L}$. In Phase 2, when the co-existent HAc and HPr was added, $\mathrm{COD}_{\mathrm{An}}$ further decreased to $40.60 \mathrm{mg} / \mathrm{L}$, and $\mathrm{M}_{\mathrm{An}, \mathrm{C}}$ efficiency reached to the peak of $94.87 \%$ (Fig.1A), which was close to the coupling DPR with simultaneous partial nitrificationendogenous denitrification (SPNED) system (91\%) (He et al., 2017b), but much higher than the post endogenous DPR system (71.20\%) (Zhao et al., 2018a) and endogenous partial DPR process (60.60 - 80.10\%) (Wang et al., 2019a). Specially, $\mathrm{TP}_{\mathrm{An}}$ was as high as $25.63 \mathrm{mg} / \mathrm{L}$ along with the TP effluent of $0.47 \mathrm{mg} / \mathrm{L}$ (Fig.1C), revealing the strong relationship between $\mathrm{M}_{\mathrm{An}, \mathrm{C}}$ efficiency and $\mathrm{TP}_{\mathrm{An}}$. Meanwhile, DPR proceeded well (DPR efficiency: 92.35\%) and contributed to a higher TN and TP removals of $85.77 \%, 91.37 \%$, respectively (Fig.1B-C). In Phase 3 (Day 80 - 100), the operation of HPr as sole carbon source conducted smoothly during the first 20 days, but $\mathrm{M}_{\mathrm{An}, \mathrm{C}}$ efficiency decreased from $90.32 \%$ to $75.17 \%$ in the last 20 days (Day 100 - 120) (Fig.1A), accompanied with the decline of $\mathrm{TP}_{\mathrm{An}}$ from $20.53 \mathrm{mg} / \mathrm{L}$ to $9.58 \mathrm{mg} / \mathrm{L}$ (Fig.1C). Accordingly, TN and TP removals dropped from $86.29 \%, 87.89 \%$ to $71.73 \%, 57.70 \%$, indicating that the types of carbon source especially the transformation of intercellular carbon source (mainly $\mathrm{M}_{\mathrm{An}, \mathrm{C}}$ ) closely related to the nutrient performance. It also highlighted the benefits of mixed carbon source in improving DPR, which coincided with the previous observations (Zhang et al., 2019a).

Due to the biodegradability of HAc and HPr, the total COD removal was around $87.32-89.41 \%$ (Fig.1A), but the removal features in the $\mathrm{A}^{2} / \mathrm{O}$ and MBBR varied significantly. In Phase 2 , the $\mathrm{A}^{2} / \mathrm{O}$ effluent $\left(\mathrm{COD}_{\mathrm{A} 2 / \mathrm{O}}=40.60 \mathrm{mg} / \mathrm{L}\right) \mathrm{was}$ similar to the final effluent $\left(\mathrm{COD}_{\mathrm{eff}}=34.67 \mathrm{mg} / \mathrm{L}\right)$, which provided favorable conditions for the enrichment of $\mathrm{AOB}$ and $\mathrm{NOB}$ in the MBBR (Chen et al., 2011), resulting in outstanding nitrifying performance with the $\mathrm{NH}_{4}{ }^{+}$effluent of $0.69 \mathrm{mg} / \mathrm{L}$ (Fig.1B). With respect to other two phases, the variation between $\mathrm{COD}_{\mathrm{A} 2 / \mathrm{O}}$ and $\mathrm{COD}_{\text {eff }}$ were $17.10 \mathrm{mg} / \mathrm{L}$ (Phase 1) and $24.82 \mathrm{mg} / \mathrm{L}$ (Phase 3) (Fig.1A), and these easily degradable COD were inevitably wasted and led to much higher $\mathrm{NH}_{4}{ }^{+}$effluent (1.50 $2.93 \mathrm{mg} / \mathrm{L}$ ) in the MBBR (Fig.1B), which was in accordance with the deteriorative TN and TP removals on Day $100-120$. Comparing with the traditional two-sludge DPR systems (e.g. A2NSBR (Zhao et al., 2016b) and AOA system (Zhao et al., 2018b)), the mixed carbon source of HAc and HPr was high-efficiently stored and utilized without wasted by oxic oxidation, 
and the bottleneck of high $\mathrm{NH}_{4}{ }^{+}$residue in effluent can also be solved, providing an alternative for reducing extra carbon addition and operational cost (Bassin et al., 2012; Kapagiannidis et al., 2013).

\subsection{Nutrient metabolism linked with different carbon sources}

The nutrient evolution was compared to show the DPR mechanism, referring to COD, VFA, TN, TP, PHA (=PHB+PHV), and Gly (Fig.2A-C). After the raw water entered, COD and VFA declined rapidly to store internal carbon sources, with the PHA contents up to $94.33,100.65,81.65 \mathrm{mgCOD} / \mathrm{L}$. In the end of anaerobic reaction, the residual COD was $72,53.20,85.30$ $\mathrm{mg} / \mathrm{L}$ and conformed to the variation of $\mathrm{M}_{\mathrm{An}, \mathrm{C}}$ efficiency (Fig.1A). Meanwhile, the more PHA stored, the higher P released, where TP reached to 20.29, 32.40, $7.98 \mathrm{mg} / \mathrm{L}$, indicating the correlation between PHA and TP (Zhang et al., 2019a).

In the anoxic zones, $\mathrm{N}$ denitrification synchronously accompanied with P removal, and PHA was gradually utilized while Gly rose steadily. Particularly, PHA utilization efficiency increased from 69.16\% (Day 40) to $75.21 \%$ (Day 80), but decreased to $48.67 \%$ (Day 120) (Fig.2D), leading to different increments of Gly ( $\Delta$ Gly: 61.27, 83.30, $30.90 \mathrm{mgCOD} / \mathrm{L}$ ). On the one hand, the residual COD was primarily utilized by OHOs and promoted the extracellular denitrification rather than PHA utilization, which can be seen from various COD downward trends in the anoxic zones ( $\triangle \mathrm{COD}$ : Phase 1, 38.40 mg/L; Phase 2, $18.65 \mathrm{mg} / \mathrm{L}$; Phase 3, $30.25 \mathrm{mg} / \mathrm{L}$ ) (Fig.2A-C). It's worth noting that the COD concentration in $\mathrm{A}^{2} / \mathrm{O}$ effluent was as high as $60.60 \mathrm{mg} / \mathrm{L}$ on Day 120, causing the sharp drop of PHA utilization efficiency. On the other hand, the type of carbon source directly affected the PHA transformation and utilization (Fig.2D), especially for the distribution of PHB and PHV. The ratios of PHB/PHA reduced from $82.86 \%$ to $67.63 \%, 46.53 \%$, where HPr had been proved to be conducive to the PHV synthesis (Yagci et al., 2007). It was also reported that PHB was mainly degraded through HAc catabolism while PHV was metabolized via HPr (Miao et al., 2016). Generally, the degradation of PHB takes precedence over PHV (Torresi et al., 2019), but PHV was more related with TN and TP removals (Zhang et al., 2019a). In Phase 2, the co-existent HAc and HPr facilitated the balance of PHB and PHV and achieved superior TN and TP removals.

Most importantly, with respect to the DPR process, removing $1 \mathrm{mg} \mathrm{NO}^{-}$and $1 \mathrm{mg} \mathrm{PO}_{4}{ }^{3-}$ consumed $3.04-4.25,6.84$ 9.82 mgPHA, respectively (Fig.2D). It was reported that removing $1 \mathrm{mg} \mathrm{PO}_{4}^{3-}$ needed $7.03-9.83 \mathrm{mgPHA}(17.22-22.89$ 
mgCOD) (Zhang et al., 2016a) in the $\mathrm{A}^{2} / \mathrm{O}$ - BCO system and 26 - $34 \mathrm{mgCOD}$ in traditional enhanced biological P removal (EBPR) systems (Grady Jr et al., 2012). By contrast, approximately 40 - 45\% carbon source can be saved in Phase 2 although it's lower than the theoretical value (50\%) (Kuba et al., 1996), exhibiting the prominent advantages of DPR technology in the $\mathrm{A}^{2} / \mathrm{O}-\mathrm{MBBR}$ system.

\subsection{Mass balance during the nutrient mechanism}

Mass balance (Day 40, 80, and 120) linked with C, N, P was further compared to elucidate the impact of carbon sources on DPR performance (Fig.3). In terms of carbon balance (RC: 98.63 - 99.02\%) (Fig.3A), under the similar proportion of $\mathrm{M}_{\mathrm{eff}, \mathrm{C}}$ (5.73- $7.60 \%$ ), $\mathrm{M}_{\mathrm{An}, \mathrm{C}}$ and $\mathrm{M}_{\mathrm{A}-\mathrm{O}, \mathrm{C}}$ as the dominant $\mathrm{COD}$ removals summed up to $75.32 \%, 76.19 \%, 66.38 \%$ due to the desired environment and sufficient anaerobic/anoxic reaction time $(8.75 \mathrm{~h})$ in the two-sludge system, which was higher than the UCT process $\left(52.70\right.$ - 67\%) (Nowak et al., 1999). Thereinto, $\mathrm{M}_{\mathrm{An}, \mathrm{C}}$ accounted for $49.37 \%, 60.38 \%$, and $55.80 \%$, corresponding to the variations of $\mathrm{M}_{\mathrm{An}, \mathrm{C}}$ efficiency (Fig.1A) and $\mathrm{TP}_{\mathrm{An}}$ (Fig.1C). In Phase 2, the majority COD were preferentially utilized by PAOs and then followed by denitrifying bacteria in the $\mathrm{A}^{2} / \mathrm{O}$ reactor, which greatly reduced the aeration consumption and enhanced the enrichment of nitrifiers (Zhang et al., 2016a). Thus, the percentage of $\mathrm{M}_{\mathrm{MBBR}, \mathrm{C}}$ was only $2.12 \%$ on Day 80 , while it reached up to 12.95\% on Day 120, resulting in the waste of carbon sources (Fig.1A) and higher $\mathrm{NH}_{4}^{+}$effluent (Fig.1B).

Apparently, $\mathrm{M}_{\mathrm{DPR}, \mathrm{N}}$ increasing from $57.01 \%$ to $65.75 \%$ (Fig.3B) presented close correlation with $\mathrm{M}_{\mathrm{An}, \mathrm{C}}$ and promoted the simultaneous TN and TP removals in Phase 1 - 2 (Fig.1A). However, due to the deterioration of DPR on Day 120, $\mathrm{M}_{\mathrm{DPR}, \mathrm{N}}$ declined to $48.68 \%$ and led to higher $\mathrm{M}_{\text {eff, }}(27.72 \%$.vs. $13.83 \%)$, accompanied with increased $\mathrm{TN}_{\text {eff }}$ concentrations (17.24 $\mathrm{mg} / \mathrm{L} . \mathrm{vs} .9 .49$ $\mathrm{mg} / \mathrm{L}$ ) (Fig.1B). Regarding to the similar SRT, $\mathrm{M}_{\mathrm{Assi}, \mathrm{N}}$ and $\mathrm{M}_{\mathrm{wS}, \mathrm{C}}$ fluctuated at $9.25-11.86 \%$ and $12.32-12.94 \%$. Particularly, nitrogen loss demonstrated the presence of $\mathrm{M}_{\mathrm{SND}, \mathrm{N}}(9.93$ - 14.35\%) in the MBBR (Fig.3B) and promoted the deep-level nutrient removal. Even so, $\mathrm{M}_{\mathrm{SND}, \mathrm{N}}$ function was indistinctive and much lower than other aerobic sludge systems (Bueno et al., 2018; He et al., 2017a) for the following reasons. Firstly, it cannot satisfy the energy requirement owing to the limited carbon residual proved by $\mathrm{M}_{\mathrm{MBBR}, \mathrm{C}}$ in the MBBR (Seifi \& Fazaelipoor, 2012). Secondly, higher $\mathrm{M}_{\mathrm{SND}, \mathrm{N}}(81.23 \%$ ) was obtained at lower DO concentration $(0.35 \mathrm{mg} / \mathrm{L}$ ) (Ma et al., 2017) because of the anoxic micro-environment in the inner parts of biofilm 
under the oxygen-limited condition, however, higher DO range $(3.50$ - $4.50 \mathrm{mg} / \mathrm{L})$ for better nitrification destroyed the microenvironment in this study. Finally, the biomass was only $2080-2210 \mathrm{mg} / \mathrm{L}$ with the biofilm thickness of $185-205 \mu \mathrm{m}$ in the MBBR (Table 1), while an optimum biofilm thickness was proved to be $600-1200 \mu \mathrm{m}$ for efficient SND (Matsumoto et al., 2007).

Moving on to the P balance ( $\mathrm{R}_{\mathrm{P}}$ : 96.33 - 97.42\%) (Fig.3C), the potential of P removal was evaluated, which further provided theoretical basis for P recovery from wastewater treatment (Zhu et al., 2018). Approximately $81.05-85.82 \%$ of $\mathrm{P}$ in influent was transferred and incorporated into the sludge $\left(\mathrm{M}_{\mathrm{WS}, \mathrm{P}}\right)$ on Day 40 and Day 80 , regardless of $\mathrm{TP}_{\mathrm{An}}$ and DPR efficiency varied significantly (Fig.1C). It should be pointed out that the short oxic zone was indispensable to ensure efficient P removal (Zhang et al., 2013) although $\mathrm{M}_{\mathrm{An}, \mathrm{C}}, \mathrm{M}_{\mathrm{A}-\mathrm{O}, \mathrm{C}}$ and $\mathrm{M}_{\mathrm{DPR}, \mathrm{N}}$ contributed a lot in the anaerobic/anoxic zones (Fig.3A-B). To maintain lower $\mathrm{M}_{\mathrm{eff}, \mathrm{P}}(11.60$ - 15.28\%), wasted sludge was discharged after the majority $\mathrm{P}$ was absorbed. However, obvious deterioration of P removal was observed on Day 120 (Fig.1C), causing reduced $\mathrm{M}_{\mathrm{WS}, \mathrm{P}}(85.82 \% \rightarrow 69.30 \%$ ) along with higher $\mathrm{M}_{\mathrm{eff}, \mathrm{P}}(11.60 \% \rightarrow 27.75 \%)$.

\subsection{Effect of carbon source on the microbial structure community}

A total number of 32923 - 57737 effective sequences were retrieved from the $\mathrm{A}^{2} / \mathrm{O}$ sludge samples (Fig.4A), and 838 1151 operational taxonomic units (OTUs) were obtained at 97\% similarity (Fig.4C). Shannon index went up from 4.61 (Day 0) to 5.30 (Day 40), 5.58 (Day 80) then dropped to 4.59 (Day 120) (Fig.4A), while Simpson index showed the same trend $(0.008,0.012,0.039,0.032)$ (Fig.4B), indicating that the species richness was improved by the addition of external carbon source. The peaks $(5.58,0.039)$ occurred with the mixture of HAc and HPr on Day 80, suggesting the highest relative abundances of bacterial community (He et al., 2018). However, Shannon (4.59) and Simpson indexes (0.032) unexpectedly fell down with more HPr on Day 120, implying that HPr was not a suitable carbon source for DPR in terms of bacterial richness, which was in accordance with the poor nutrient metabolism performance (Fig.1, Fig.2, Fig.3).

Venn diagram further exhibited the difference caused by carbon sources, where only 408 OTUs were shared by four sludge samples (Fig.4C).The OTUs in $\mathrm{A}^{2} / \mathrm{O}$ sludge samples (838 - 995) were lower than seed sludge (1151), implying the 
shift of more concentrated microbial community (He et al., 2017b). Specially, the addition of HAc and HPr occupied 92 unique OTUs on Day 80, but single HAc or HPr only possessed 40, 20 unique OTUs. Combining with the microbial diversity (Fig.4A-B), the results showed that more disparate microbial distributions were shared under the mixture of HAc and HPr, which had been proved that mixed carbon source decidedly shaped the bacterial community (He et al., 2018).

The functional bacteria abundances at phylum level were investigated, and the addition of carbon sources significantly changed the microbial community structures from the seed sludge (Fig.5A). Proteobacteria (30.67 - 42.62\%), Chloroflexi (15.95 - 25.93\%), and Bacteroidetes (2.12 - 21.97\%) were the three dominant phyla, which had been identified to contain PAOs and DPAOs (Zhang et al., 2016b; Zhang et al., 2019a). Actinobacteria commonly detected in activated sludge systems (Wang et al., 2019b) and Saccharibacteria responsible for organic matter degradation as well as denitrification (Zhou et al., 2015 ) decreased from $24.20 \%$ (Day 0: $15.10 \%+9.10 \%$ ), $21.00 \%$ (Day $40: 9.73 \%+11.27 \%$ ) to $3.96 \%$ (Day $80: 1.30 \%+$ 2.66\%), $4.20 \%$ (Day 120: 1.82\% + 2.38\%), indicating the adverse impact of HPr on COD removal (Fig.1A). Parcubacteria identified in most anaerobic/anoxic metabolism using $\mathrm{NO}_{3}^{-}$instead of $\mathrm{O}_{2}$ (Nelson \& Stegen, 2015) occupied a larger proportion of 14.96\% in Phase 2 (vs. 0.6\% in Phase 1 and 3.6\% in Phase 3) and enhanced the DPR performance (Fig.1-3). Moreover, Chlorobi of the same group with Bacteroidetes was $6.11 \%$ in Phase 2, which was much higher than other samples $(0-1 \%)$.

Further comparison of the dominant bacterial at genus level was conducted to reveal the microbial community evolution (Table 2). Accumulibacter classified as PAOs (belonging to Proteobacteria) benefited from 0.39\% (Day 0), 8.49\% (Day 40), 18.72\% (Day 80) to 10.23\% (Day 120), and Acinetobacter related to PAOs (Gebremariam et al., 2011) also increased from $1.06 \%$ (Day 0) to 1.35 - 2.98\% (Phase 1 - 3). Dechloromonas (1.52 - 4.78\%) and Pseudomonas (0.72 - 3.27\%) belonging to DPAOs (Xu et al., 2019) reached to the peak on Day 80 when HAc and HPr coexisted. Due to the enhancement of DPR, the bacteria groups of Accumulibacter, Acinetobacter, Dechloromonas and Pseudomonas occupied 14.34\%, 29.13\%, and 16.18\% in the $\mathrm{A}^{2} / \mathrm{O}$ sludge while they were hardly detected in the seed sludge (1.70\%). However, Competibacter and Defluviicoccus known as GAOs (Dai et al., 2007) were the dominant species with the total percentages of 1.85\% (Day 0), 5.27\% (Day 40), 
$20.28 \%$ (Day 80), 27.98\% (Day 120), respectively. GAOs showed a more inferior position to HAc than HPr, although they were able to metabolize both HAc and HPr (Adrian et al., 2006; Zhang et al., 2019a). According to the metabolic model of PAO-GAOs (Lopez-Vazquez et al., 2009), PAOs exhibited an advantage over GAOs when HAc and HPr were simultaneously fed as compared to cases when the single carbon source was supplied. Beyond that, the abundance of OHOs in terms of Thauera (0.25 - 2.39\%), Comamonas (1.39 - 3.03\%), Azospira (0.07 - 0.19\%), Thermomonas (0.02 - 0.05\%) decreased comparing with the seed sludge, showing that exogenous denitrification was suppressed. Nevertheless, Anaerolineaceae and Zoogloea considered as filamentous microorganism increased from $1.13 \%$ and $0.94 \%$ to $1.49-11.87 \%$ and $2.98-4.31 \%$, respectively, playing the predominant potential in granular sludge without filamentous-type bulking (He et al., 2020; Zhang et al., 2016b). Thanks to the shorter SRT in the $\mathrm{A}^{2} / \mathrm{O}$ reactor, Nitrosomonas and Nitrosomonadaceae identified as AOB declined from $4.03 \%(2.75 \%+1.28 \%)$ to $0.83 \%(0.45 \%+0.38 \%), 0.33 \%(0.16 \%+0.17 \%), 0.25 \%(0.04 \%+0.21 \%)$, while Nitrospira identified as NOB dropped from $3.01 \%$ to $0.10-0.48 \%$ (Table 2).

When it comes to the MBBR (Fig.5B), Proteobacteria which was common in a broad range of environments and lifestyles accounted for $77.60-81.79 \%$, and Planctomycetes and Nitrospira responsible for nitrification (Wang et al., 2014) increased from $2.70 \%\left(\mathrm{~N}_{1}: 1.14 \%+1.56 \%\right)$ to $11.70 \%\left(\mathrm{~N}_{2}: 4.64 \%+7.06 \%\right)$, and $21.91 \%\left(\mathrm{~N}_{3}: 6.48 \%+15.43 \%\right)$. Actinobacteria belonging to filamentous could decompose many organic matters (Puttaswamygowda et al., 2019), decreasing from $4.67 \%$ to $2.97 \%, 2.28 \%$ because of the decrescent COD contents from $\mathrm{N}_{1}$ to $\mathrm{N}_{3}$. Chloroflexi $(1.61-2.78 \%)$, Bacteroidetes (1.66 - 3.65\%), and Chlamydiae (1.25 - 2.31\%) were similar in three biofilm samples, implying they were not notably affected by DO. At genus level (Table 2), Nitrosomonas and Nitrosomonadaceae as the typical AOB (Chen et al., 2006) increased from $2.33 \%(2.18 \%+0.15 \%)$ to $16.03 \%(15.24 \%+0.79 \%), 21.80 \%(20.75 \%+1.05 \%)$, while Nitrospira as the typical NOB rose from $1.56 \%$ to $7.06 \%, 15.43 \%$. The total abundance of AOB and NOB $(3.89 \%, 23.09 \%$, and $37.23 \%)$ gradually enriched along the flow direction owing to the special three-stage mode in the MBBR (Zhang et al., 2016b). Theoretically, organic matter often prevents or inhibits the $\mathrm{O}_{2}$ utilization in nitrification (Pan et al., 2020), leading to adverse environment for $\mathrm{NH}_{4}{ }^{+}$ removal and nitrifiers enrichment (Zhu et al., 2014). On account of lower $\mathrm{M}_{\mathrm{MBBR}, \mathrm{C}}$ (Fig.3A), the percentages of AOB (17.88\%) 
and NOB (21.71\%) were similar to the nitrifying SBR but much higher than a pilot nitrifying MBBR with AOB of $6.5-7.0 \%$ and NOB of $2.3-3.8 \%$ (Young et al., 2017). Nevertheless, OHOs still occupied the majority due to a higher proliferation rate (Berg et al., 2009). Thermomonas related to denitrification (Xing et al., 2018) accounted for $40.14 \%$ in $\mathrm{N}_{1}$, but reduced to $12.22 \%\left(\mathrm{~N}_{2}\right)$ and $2.65 \%\left(\mathrm{~N}_{3}\right)$. Anaerolineaceae and Zoogloea isolated from granular sludge (Yamada et al., 2006) and attached for biofilm skeleton (Zhang et al., 2016c) varied between $0.74-1.05 \%$ and $6.78-8.03 \%$. Pseudomonas with certain SND abilities during the mass transfer (He et al., 2016) accounted for $0.84-2.19 \%$, contributing to $\mathrm{M}_{\mathrm{SND}, \mathrm{N}}$ for improved TN removals (Fig.3B).

\subsection{Operation optimization based on the utilizing rules of HAc and $\mathrm{HPr}$}

It was reported that HAc and HPr ranged around $49-71 \%$ and $24-33 \%$ of the total influent VFAs in WWTPs (Chen et al., 2004), so this study proposed an operation strategy and showed important application value to optimize carbon source addition for advanced nutrient removal. Firstly, the types of carbon source especially the transformation and utilization of PHA closely related to the nutrient performance, and the co-existent HAc and HPr facilitated the balance of PHB and PHV. Secondly, mass balance contributed to the deep comprehension of DPR metabolic pathways with the purpose of economic operation, which also provides reference for other BNR systems. Finally, the mixture of HAc and HPr promoted the bacterial richness, and certain special genera (e.g. Actinobacteria, Saccharibacteria, Parcubacteria and Chlorobi) played important roles in operation stability although PAOs and GAOs were the two main competitive groups. However, the above advantages cannot achieve unless the economical operation (e.g. carbon source, aeration consumption and sludge production) (Ji et al., 2019; Xu et al., 2020) is fully considered, especially in real wastewater with complex and fluctuant water quality.

\section{Conclusion}

In the $\mathrm{A}^{2} / \mathrm{O}$ - MBBR system, high-efficient nutrient removals were obtained at the mixed carbon source condition (HAc:HPr $=1: 1$ ), which not only achieved higher $\mathrm{M}_{\mathrm{An}, \mathrm{C}}$ efficiency $(94.87 \%), \mathrm{TP}_{\mathrm{An}}(25.63 \mathrm{mg} / \mathrm{L})$, and PHA utilization (75.21\%), but also exhibited obvious operational advantage of saving 40 - 45\% carbon source. Mass balance presented the peaks of 
$\mathrm{M}_{\mathrm{DPR}, \mathrm{N}}(65.75 \%)$ and $\mathrm{M}_{\mathrm{WS}, \mathrm{P}}(85.82 \%)$ owing to the contribution of $\mathrm{M}_{\mathrm{An}, \mathrm{C}}$ and $\mathrm{M}_{\mathrm{A}-\mathrm{O}, \mathrm{C}}(76.19 \%)$, although $\mathrm{M}_{\mathrm{SND}, \mathrm{N}}(9.93-14.35 \%)$ also promoted the deep-level nutrient removal. The species richness of Shannon and Simpson was improved with more concentrated OTUs (838 - 995), where Accumulibacter, Acinetobacter, Dechloromonas and Pseudomonas conducting DPR summed up to 14.34 - 29.13\% and exhibited an advantage over Competibacter and Defluviicoccus when HAc and HPr were simultaneously fed. Nitrosomonas, Nitrosomonadaceae and Nitrospira dominating nitrification increased form 3.89\%, 23.09\% to $37.23 \%$ along the three-stage MBBR.

\section{Acknowledgments}

This research was financially supported by the Natural Science Foundation of China (Grant No. 51808482), Natural Science Foundation of Jiangsu Province (Grants No. BK20170506), and Postdoctoral Science Foundation (Grants No. 2018M632392).

\section{Appendix A. Supplementary data}

Supplementary data to this article can be found in the online version. 


\section{References}

Adrian, O., Zeng, R.J., Saunders, A.M., Blackall, L.L., Jürg, K., Zhiguo, Y. 2006. Anaerobic and aerobic metabolism of glycogenaccumulating organisms selected with propionate as the sole carbon source. Microbiology, 152(9), 2767-78.

Ahn, J., Daidou, T., Tsuneda, S., Hirata, A. 2002. Characterization of denitrifying phosphate-accumulating organisms cultivated under different electron acceptor conditions using polymerase chain reaction-denaturing gradient gel electrophoresis assay. Water Research, 36(2), 403-412.

AWWA. 2005. Standard Methods for the Examination of Water and Wastewater. 21st ed. American Water Works Association.

Bassin, J.P., Kleerebezem, R., Dezotti, M., Loosdrecht, M.C.M.V. 2012. Simultaneous nitrogen and phosphate removal in aerobic granular sludge reactors operated at different temperatures. Water Research, 46(12), 3805-3816.

Berg, K.A., Lyra, C., Sivonen, K., Paulin, L., Suomalainen, S., Tuomi, P., Rapala, J. 2009. High diversity of cultivable heterotrophic bacteria in association with cyanobacterial water blooms. Isme Journal, 3(3), 314-325.

Brown, P., Ong, S.K., Lee, Y.-W. 2011. Influence of anoxic and anaerobic hydraulic retention time on biological nitrogen and phosphorus removal in a membrane bioreactor. 270(1-3), 227-232.

Bueno, R.F., Piveli, R.P., Campos, F., Sobrinho, P.A. 2018. Simultaneous nitrification and denitrification in the activated sludge systems of continuous flow. Environmental Technology, 39(20), 2641-2652.

Cai, W., Huang, W., Li, H., Sun, B., Xiao, H., Zhang, Z., Lei, Z. 2016. Acetate favors more phosphorus accumulation into aerobic granular sludge than propionate during the treatment of synthetic fermentation liquor. Bioresour Technol, 214, $596-603$.

Carvalheira, M., Oehmen, A., Carvalho, G., Reis, M.A.M. 2014. The effect of substrate competition on the metabolism of polyphosphate accumulating organisms (PAOs). Water Research, 64(7), 149-159.

Chen, S., Ling, J., Blancheton, J.-P. 2006. Nitrification kinetics of biofilm as affected by water quality factors. Aquacultural Engineering, 34(3), 179-197.

Chen, Y., Li, B., Ye, L., Peng, Y. 2015. The combined effects of COD/N ratio and nitrate recycling ratio on nitrogen and phosphorus removal in anaerobic/anoxic/aerobic (A 2 /O)-biological aerated filter (BAF) systems. Biochemical Engineering Journal, 93(10), 235-242.

Chen, Y., Peng, C., Wang, J., Ye, L., Zhang, L., Peng, Y. 2011. Effect of nitrate recycling ratio on simultaneous biological nutrient removal in a novel anaerobic/anoxic/oxic (A 2 /O)-biological aerated filter (BAF) system. Bioresource Technology, 102(10), 5722-5727.

Chen, Y., Randall, A.A., McCue, T. 2004. The efficiency of enhanced biological phosphorus removal from real wastewater affected by different ratios of acetic to propionic acid. Water Res, 38(1), 27-36.

Chen, Y., Wen, Y., Zhou, Q., Vymazal, J. 2014. Effects of plant biomass on nitrogen transformation in subsurface-batch constructed wetlands: A stable isotope and mass balance assessment. Water Research, 63, 158-167.

Chuang, S.-H., Ouyang, C.-F. 2000. The biomass fractions of heterotrophs and phosphate-accumulating organisms in a nitrogen and phosphorus removal system. Water Research, 34(8), 2283-2290.

Dai, Y., Yuan, Z., Wang, X., Oehmen, A., Keller, J. 2007. Anaerobic metabolism of Defluviicoccus vanus related glycogen accumulating organisms (GAOs) with acetate and propionate as carbon sources. Water Research, 41(9), 1885-1896.

Filipe, C.D.M., Daigger, G.T., Grady Jr, C.P.L. 2001. pH as a Key Factor in the Competition Between Glycogen-Accumulating Organisms and Phosphorus-Accumulating Organisms. Water Environment Research, 73(2), 223-232.

Gebremariam, S.Y., Beutel, M.W., Christian, D., Hess, T.F. 2011. Research Advances and Challenges in the Microbiology of Enhanced Biological Phosphorus Removal-A Critical Review. Water Environment Research 83(3), 195-219.

Grady Jr, C.L., Daigger, G.T., Love, N.G., Filipe, C.D. 2012. Biological wastewater treatment. CRC Press.

He, Q., Chen, L., Zhang, S., Wang, L., Liang, J., Xia, W., Wang, H., Zhou, J. 2018. Simultaneous nitrification, denitrification and phosphorus removal in aerobic granular sequencing batch reactors with high aeration intensity: Impact of aeration time. Bioresource Technology, 263, 214-222.

He, Q., Wang, H., Chen, L., Gao, S., Zhang, W., Song, J., Yu, J. 2020. Elevated salinity deteriorated enhanced biological phosphorus removal in an aerobic granular sludge sequencing batch reactor performing simultaneous nitrification, denitrification and phosphorus removal. Journal of Hazardous Materials, 390, 121782. 
He, Q., Zhang, W., Zhang, S., Wang, H. 2017a. Enhanced nitrogen removal in an aerobic granular sequencing batch reactor performing simultaneous nitrification, endogenous denitrification and phosphorus removal with low superficial gas velocity. Chemical Engineering Journal, 326, 1223-1231.

He, Q., Zhang, W., Zhang, S., Zou, Z., Wang, H. 2017b. Performance and microbial population dynamics during stable operation and reactivation after extended idle conditions in an aerobic granular sequencing batch reactor. Bioresource Technology, 238, 116-121.

He, T., Li, Z., Quan, S., Yi, X., Ye, Q. 2016. Heterotrophic nitrification and aerobic denitrification by Pseudomonas tolaasii Y-11 without nitrite accumulation during nitrogen conversion. Bioresource Technology, 200, 493-499.

Henze, M., Harremoës, P., Jansen, J.l.C., Arvin, E. 1999. Wastewater treatment. Biological and chemical processes. China Architecture \& Building Press.

Ji, J., Peng, Y., Li, X., Zhang, Q. 2019. Stable long-term operation and high nitrite accumulation of an endogenous partialdenitrification (EPD) granular sludge system under mainstream conditions at low temperature. Bioresource Technology, 289, 121634.

Kapagiannidis, A.G., Zafiriadis, I., Aivasidis, A. 2013. Comparison between aerobic and anoxic metabolism of denitrifying-EBPR sludge: effect of biomass poly-hydroxyalkanoates content. New Biotechnology, 30(2), 227-237.

Kuba, T., Loosdrecht, M.C.M.v., Heijnen, J.J. 1996. Phosphorus and nitrogen removal with minimal COD requirement by integration of denitrifying dephosphatation and nitrification in a two-sludge system. Water Research, 30(7), 0-1710.

Lee, J.-K., Choi, C.-K., Lee, K.-H., Yim, S.-B. 2008. Mass balance of nitrogen, and estimates of COD, nitrogen and phosphorus used in microbial synthesis as a function of sludge retention time in a sequencing batch reactor system. Bioresource Technology, 99(16), 7788-7796.

Lopez-Vazquez, C.M., Oehmen, A., Hooijmans, C.M., Brdjanovic, D., Gijzen, H.J., Yuan, Z.G., Loosdrecht, M.C.M.V. 2009. Modeling the PAO-GAO competition: Effects of carbon source, $\mathrm{pH}$ and temperature. Water Research, 43(2), $450-62$.

Ma, W., Han, Y., Ma, W., Han, H., Zhu, H., Xu, C., Li, K., Wang, D. 2017. Enhanced nitrogen removal from coal gasification wastewater by simultaneous nitrification and denitrification (SND) in an oxygen-limited aeration sequencing batch biofilm reactor. Bioresource Technology, 244, 84-91.

Manser, R. 2005. Population dynamics and kinetics of nitrifying bacteria in membrane and conventional activated sludge plants.

Marcelino, M., Wallaert, D., Guisasola, A., Baeza, J.A. 2011. A two-sludge system for simultaneous biological C, N and P removal via the nitrite pathway. Water Sci Technol, 64(5), 1142-1147.

Matsumoto, S., Terada, A., Tsuneda, S. 2007. Modeling of membrane-aerated biofilm: Effects of C/N ratio, biofilm thickness and surface loading of oxygen on feasibility of simultaneous nitrification and denitrification. Biochemical Engineering Journal, 37(1), 98-107.

Miao, L., Wang, S., Li, B., Cao, T., Zhang, F., Wang, Z., Peng, Y. 2016. Effect of carbon source type on intracellular stored polymers during endogenous denitritation (ED) treating landfill leachate. Water Research, 100, 405-412.

Nelson, W., Stegen, J. 2015. The reduced genomes of Parcubacteria (OD1) contain signatures of a symbiotic lifestyle. Frontiers in Microbiology, 6, 713.

Nowak, O., Franz, A., Svardal, K., Müller, V., Kühn, V. 1999. Parameter estimation for activated sludge models with the help of mass balances. Water Science and Technology, 39(4), 113-120.

Oehmen, A., Lemos, P.C., Carvalho, G., Yuan, Z., Keller, J., Blackall, L.L., Reis, M.A.M. 2007. Advances in enhanced biological phosphorus removal: From micro to macro scale. Water Research, 41(11), 2271-2300.

Oehmen, A., Saunders, A.M., Vives, M.T., Yuan, Z., Keller, J. 2006. Competition between polyphosphate and glycogen accumulating organisms in enhanced biological phosphorus removal systems with acetate and propionate as carbon sources Journal of Biotechnology, 123(1), 22-32.

Oehmen, A., Yuan, Z., Blackall, L.L., Keller, J. 2010. Comparison of acetate and propionate uptake by polyphosphate accumulating organisms and glycogen accumulating organisms. Biotechnology \& Bioengineering, 91(2), 162-168.

Pan, Z., Zhou, J., Lin, Z., Wang, Y., Zhao, P., Zhou, J., Liu, S., He, X. 2020. Effects of COD/TN ratio on nitrogen removal efficiency, microbial community for high saline wastewater treatment based on heterotrophic nitrification-aerobic denitrification process. Bioresource Technology, 301, 122726. 
Peng, Y., Ge, S. 2011. Enhanced nutrient removal in three types of step feeding process from municipal wastewater. Bioresource Technology, 102(11), 6405-6413.

Pijuan, M., Casas, C., Baeza, J.A. 2009. Polyhydroxyalkanoate synthesis using different carbon sources by two enhanced biological phosphorus removal microbial communities. Process Biochemistry, 44(1), 97-105.

Puttaswamygowda, G.H., Olakkaran, S., Antony, A., Kizhakke Purayil, A. 2019. Present Status and Future Perspectives of Marine Actinobacterial Metabolites. in: Recent Developments in Applied Microbiology and Biochemistry, (Ed.) V. Buddolla, Academic Press, pp. 307-319.

Rollemberg, S.L.d.S., de Oliveira, L.Q., Barros, A.R.M., Melo, V.M.M., Firmino, P.I.M., dos Santos, A.B. 2019. Effects of carbon source on the formation, stability, bioactivity and biodiversity of the aerobic granule sludge. Bioresource Technology, 278, 195-204.

Seifi, M., Fazaelipoor, M.H. 2012. Modeling simultaneous nitrification and denitrification (SND) in a fluidized bed biofilm reactor. Applied Mathematical Modelling, 36(11), 5603-5613.

Torresi, E., Tang, K., Deng, J., Sund, C., Smets, B.F., Christensson, M., Andersen, H.R. 2019. Removal of micropollutants during biological phosphorus removal: Impact of redox conditions in MBBR. Science of The Total Environment, 663, $496-506$.

Wang, X., Zhao, J., Yu, D., Chen, G., Du, S., Zhen, J., Yuan, M. 2019a. Stable nitrite accumulation and phosphorous removal from nitrate and municipal wastewaters in a combined process of endogenous partial denitrification and denitrifying phosphorus removal (EPDPR). Chemical Engineering Journal, 355, 560-571.

Wang, X., Zhao, J., Yu, D., Du, S., Yuan, M., Zhen, J. 2019b. Evaluating the potential for sustaining mainstream anammox by endogenous partial denitrification and phosphorus removal for energy-efficient wastewater treatment. Bioresource Technology, 284, 302-314.

Wang, Y., Jiang, F., Zhang, Z., Xing, M., Lu, Z., Wu, M., Yang, J., Peng, Y. 2010. The long-term effect of carbon source on the competition between polyphosphorus accumulating organisms and glycogen accumulating organism in a continuous plugflow anaerobic/aerobic (A/O) process. Bioresource Technology, 101(1), 98-104.

Wang, Y., li, L., Xiao, M., Ximao, L., Mianli, P., Xiaohu, D. 2014. Bio-characteristics of anammox bacteria and CANON anammox process. Acta Scientiae Circumstantiae, 34(6), 1362-1374.

Xing, W., Li, J., Li, P., Wang, C., Cao, Y., Li, D., Yang, Y., Zhou, J., Zuo, J. 2018. Effects of residual organics in municipal wastewater on hydrogenotrophic denitrifying microbial communities. Journal of Environmental Sciences, 65, 262-270.

Xu, X., Ma, B., Lu, W., Feng, D., Wei, Y., Ge, C., Peng, Y. 2020. Effective nitrogen removal in a granule-based partialdenitrification/anammox reactor treating low C/N sewage. Bioresource Technology, 297, 122467.

Xu, X., Qiu, L., Wang, C., Yang, F. 2019. Achieving mainstream nitrogen and phosphorus removal through Simultaneous partial Nitrification, Anammox, Denitrification, and Denitrifying Phosphorus Removal (SNADPR) process in a single-tank integrative reactor. Bioresource Technology, 284, 80-89.

Yagci, N., Cokgor, E.U., Artan, N., Randall, C., Orhon, D. 2007. The effect of substrate on the composition of polyhydroxyalkanoates in enhanced biological phosphorus removal. Journal of Chemical Technology \& Biotechnology, 82(3), 295-303.

Yamada, T., Sekiguchi, Y.S., Imachi, H., Ohashi, A., Harada, H., Kamagata, Y. 2006. Anaerolinea thermolimosa sp. nov., Levilinea saccharolytica gen. nov., sp. nov. and Leptolinea tardivitalis gen. nov., sp. nov., novel filamentous anaerobes, and description of the new classes Anaerolineae classis nov. and Caldilineae classis nov. in. International Journal of Systematic \& Evolutionary Microbiology, 56, 1331-1340.

Yang, G., Wang, D., Yang, Q., Zhao, J., Liu, Y., Wang, Q., Zeng, G., Li, X., Li, H. 2018. Effect of acetate to glycerol ratio on enhanced biological phosphorus removal. Chemosphere, 196, 78-86.

Young, B., Delatolla, R., Kennedy, K., Laflamme, E., Stintzi, A. 2017. Low temperature MBBR nitrification: Microbiome analysis. Water Research, 111, 224-233.

Zhang, M., Peng, Y., Wang, C., Wang, C., Zhao, W., Zeng, W. 2016a. Optimization denitrifying phosphorus removal at different hydraulic retention times in a novel anaerobic anoxic oxic-biological contact oxidation process. Biochemical Engineering Journal, 106, 26-36.

Zhang, M., Qing, Y., Jianhua, Z., Wang, C., Shuying, W., Yongzhen, P. 2016b. Enhancement of denitrifying phosphorus removal 
and microbial community of long-term operation in an anaerobic anoxic oxic-biological contact oxidation system. Journal of Bioscience \& Bioengineering, 122(4), 456-466.

Zhang, M., Wang, C., Peng, Y., Wang, S., Jia, F., Zeng, W. 2016c. Organic substrate transformation and sludge characteristics in the integrated anaerobic anoxic oxic-biological contact oxidation $(\mathrm{A} 2 / \mathrm{O}-\mathrm{BCO})$ system treating wastewater with low carbon/nitrogen ratio. Chemical Engineering Journal, 283, 47-57.

Zhang, M., Wang, Y., Fan, Y., Liu, Y., Yu, M., He, C., Wu, J. 2019a. Bioaugmentation of low C/N ratio wastewater: Effect of acetate and propionate on nutrient removal, substrate transformation, and microbial community behavior. Bioresource Technology, 122465.

Zhang, M., Yu, M., Wang, Y., He, C., Pang, J., Wu, J. 2019b. Operational optimization of a three-stage nitrification moving bed biofilm reactor (NMBBR) by obtaining enriched nitrifying bacteria: Nitrifying performance, microbial community, and kinetic parameters. Science of The Total Environment, 697, 134101.

Zhang, M., Zhu, C., Pan, T., Fan, Y., Liu, Y., He, C., Gu, X., Wu, J. 2020. Elucidating sludge characteristic, substrate transformation and microbial evolution in a two-sludge denitrifying phosphorus removal system under the impact of HRT. Journal of Environmental Management, 262, 110391.

Zhang, W., Peng, Y., Ren, N., Liu, Q., Chen, Y. 2013. Improvement of nutrient removal by optimizing the volume ratio of anoxic to aerobic zone in AAO-BAF system. Chemosphere, 93(11), 2859-2863.

Zhao, J., Wang, X., Li, X., Jia, S., Peng, Y. 2018a. Combining partial nitrification and post endogenous denitrification in an EBPR system for deep-level nutrient removal from low carbon/nitrogen $(\mathrm{C} / \mathrm{N})$ domestic wastewater. Chemosphere, 210, $19-28$.

Zhao, W., Huang, Y., Wang, M., Pan, C., Li, X., Peng, Y., Li, B. 2018b. Post-endogenous denitrification and phosphorus removal in an alternating anaerobic/oxic/anoxic (AOA) system treating low carbon/nitrogen $(\mathrm{C} / \mathrm{N})$ domestic wastewater. Chemical Engineering Journal, 339, 450-458.

Zhao, W., Yong, Z., Lv, D., Wang, M., Peng, Y., Li, B. 2016a. Advanced nitrogen and phosphorus removal in the pre-denitrification anaerobic/anoxic/aerobic nitrification sequence batch reactor (pre-A 2 NSBR) treating low carbon/nitrogen (C/N) wastewater. Chemical Engineering Journal, 302, 296-304.

Zhao, W., Zhang, Y., Lv, D., Wang, M., Peng, Y., Li, B. 2016b. Advanced nitrogen and phosphorus removal in the pre-denitrification anaerobic/anoxic/aerobic nitrification sequence batch reactor (pre-A2NSBR) treating low carbon/nitrogen (C/N) wastewater. Chemical Engineering Journal, 302, 296-304.

Zhou, Z., Qiao, W., Xing, C., An, Y., Shen, X., Ren, W., Jiang, L.-m., Wang, L. 2015. Microbial community structure of anoxicoxic-settling-anaerobic sludge reduction process revealed by 454-pyrosequencing. Chemical Engineering Journal, 266, 249-257.

Zhu, H., Yan, B., Xu, Y., Guan, J., Liu, S. 2014. Removal of nitrogen and COD in horizontal subsurface flow constructed wetlands under different influent $\mathrm{C} / \mathrm{N}$ ratios. Ecological Engineering, 63, 58-63.

Zhu, Z., Chen, W., Tao, T., Li, Y. 2018. A novel AAO-SBSPR process based on phosphorus mass balance for nutrient removal and phosphorus recovery from municipal wastewater. Water Research, 144, 763-773. 


\section{Table captions}

Table 1 Operation conditions of the $\mathrm{A}^{2} / \mathrm{O}$ - MBBR system

Table 2 Phylogenetic classification of the dominant species involved in $\mathrm{A}^{2} / \mathrm{O}$ and $\mathrm{MBBR}$ at genus level 
Table 1 Operation conditions of the $\mathrm{A}^{2} / \mathrm{O}$ - MBBR system

a:

\begin{tabular}{|c|c|c|c|c|c|c|c|}
\hline Phase & $\begin{array}{l}\text { Duration } \\
\text { (d) }\end{array}$ & $\begin{array}{l}\mathrm{HAc}^{\mathrm{b}} \\
(\mathrm{mg} / \mathrm{L})\end{array}$ & $\begin{array}{c}\operatorname{HPr}^{\mathrm{b}} \\
(\mathrm{mg} / \mathrm{L})\end{array}$ & $\begin{array}{l}\mathrm{VSS}_{1}{ }^{\mathrm{c}} \\
(\mathrm{mg} / \mathrm{L})\end{array}$ & $\begin{array}{l}\mathrm{VSS}_{2}{ }^{\mathrm{d}} \\
(\mathrm{mg} / \mathrm{L})\end{array}$ & $\begin{array}{l}\text { Biofilm } \\
\text { thickness } \\
\qquad(\mu \mathrm{m})\end{array}$ & Other parameters \\
\hline 1 & $1-40^{a}$ & 250 & 0 & $4080 \pm 15$ & $2140 \pm 18$ & $194 \pm 10$ & $\begin{array}{c}\mathrm{Q}=67.20 \mathrm{~L} / \mathrm{d} \\
\mathrm{C} / \mathrm{N}=3.85 \pm 0.15\end{array}$ \\
\hline 2 & $41-80^{a}$ & 125 & 125 & $3975 \pm 20$ & $2210 \pm 15$ & $205 \pm 12$ & $\begin{array}{c}\text { HRT }=10 \mathrm{~h} \\
\text { Temperature }=22 \pm 3{ }^{\circ} \mathrm{C} \\
\text { volume ratio }=2: 5: 1\end{array}$ \\
\hline 3 & $81-120^{a}$ & 0 & 250 & $4120 \pm 10$ & $2080 \pm 20$ & $185 \pm 15$ & $\begin{array}{l}\mathrm{r}=100 \% \\
\mathrm{R}=400 \%\end{array}$ \\
\hline
\end{tabular}

sampling dates for mass balance, nutrient metabolism and microbial community analysis (Day 40, Day 80, Day 120);

b: the fluctuant range of carbon source concentration at $\pm 10 \mathrm{mg} / \mathrm{L}$;

c: the average VSS in the $\mathrm{A}^{2} / \mathrm{O}$ reactor;

d: the average VSS of $\mathrm{N}_{1}, \mathrm{~N}_{2}$, and $\mathrm{N}_{3}$;

e: the average biofilm thickness of $\mathrm{N}_{1}, \mathrm{~N}_{2}$, and $\mathrm{N}_{3}$. 
Table 2 Phylogenetic classification of the dominant species involved in the $\mathrm{A}^{2} / \mathrm{O}$ and $\mathrm{MBBR}$ at genus level

\begin{tabular}{|c|c|c|c|c|c|c|c|c|}
\hline \multirow{2}{*}{\multicolumn{2}{|c|}{$\begin{array}{c}\text { Species percentage } \\
(\%)\end{array}$}} & \multicolumn{7}{|c|}{ Samples } \\
\hline & & Day 0 & Day 40 & Day 80 & Day 120 & Day $120-\mathrm{N}_{1}$ & Day $120-\mathrm{N}_{2}$ & Day $120-\mathrm{N}_{3}$ \\
\hline \multirow[t]{2}{*}{ PAOs } & Accumulibacter & 0.39 & 8.49 & 18.72 & 10.23 & - & - & - \\
\hline & Acinetobacter & 1.06 & 1.35 & 2.36 & 2.98 & - & - & - \\
\hline \multirow[t]{2}{*}{ DPAOs } & Dechloromonas & 0.09 & 1.52 & 4.78 & 2.15 & 0.01 & 0 & 0.03 \\
\hline & Pseudomonas & 0.16 & 2.98 & 3.27 & 0.72 & 1.09 & 0.84 & 2.19 \\
\hline \multirow[t]{2}{*}{ GAOs } & Competibacter & 0.89 & 2.49 & 12.72 & 17.23 & - & - & - \\
\hline & Defluviicoccus & 0.96 & 2.78 & 7.56 & 10.75 & - & - & - \\
\hline \multirow[t]{7}{*}{ OHOs } & Thauera & 5.18 & 2.39 & 0.25 & 0.78 & - & - & - \\
\hline & Anaerolineaceae & 1.13 & 1.49 & 10.58 & 11.87 & 1.05 & 0.93 & 0.74 \\
\hline & Comamonas & 10.25 & 6.15 & 1.39 & 3.03 & 1.29 & 0.11 & 0.06 \\
\hline & Zoogloea & 0.94 & 3.45 & 2.98 & 4.31 & 8.03 & 6.35 & 6.78 \\
\hline & Azospira & 3.63 & 0.08 & 0.07 & 0.19 & 0.05 & 0.01 & 0.03 \\
\hline & Thermomonas & 3.05 & 0.02 & 0.05 & 0.05 & 40.14 & 12.22 & 2.65 \\
\hline & Denitratisoma & 0.18 & 1.02 & 0.12 & 0.03 & 0.92 & 0.45 & 0 \\
\hline \multirow[t]{2}{*}{$\mathrm{AOB}$} & Nitrosomonas & 2.75 & 0.45 & 0.16 & 0.04 & 2.18 & 15.24 & 20.75 \\
\hline & Nitrosomonadaceae & 1.28 & 0.38 & 0.17 & 0.21 & 0.15 & 0.79 & 1.05 \\
\hline NOB & Nitrospira & 3.01 & 0.29 & 0.10 & 0.48 & 1.56 & 7.06 & 15.43 \\
\hline
\end{tabular}




\section{Figure captions}

Fig.1 Profiles of nutrient removal in the $\mathrm{A}^{2} / \mathrm{O}-\mathrm{MBBR}$ system (A: COD; B: TN and $\mathrm{NH}_{4}^{+}$; C: TP)

Fig.2 Nutrient evolution along the reaction zones (A, B, C) and PHA transformation and utilization (D) in the $\mathrm{A}^{2} / \mathrm{O}$ reactor

Fig.3 Mass balance analysis in the A²/O - MBBR system (A: Carbon; B: Nitrogen; C: Phosphorus)

Fig.4 Bacterial biodiversity based on OTUs (A: Shannon index; B: Simpson index; C: Venn diagram)

Fig.5 Microbial community structures of sludge (A) and biofilm (B) samples at phylum level 

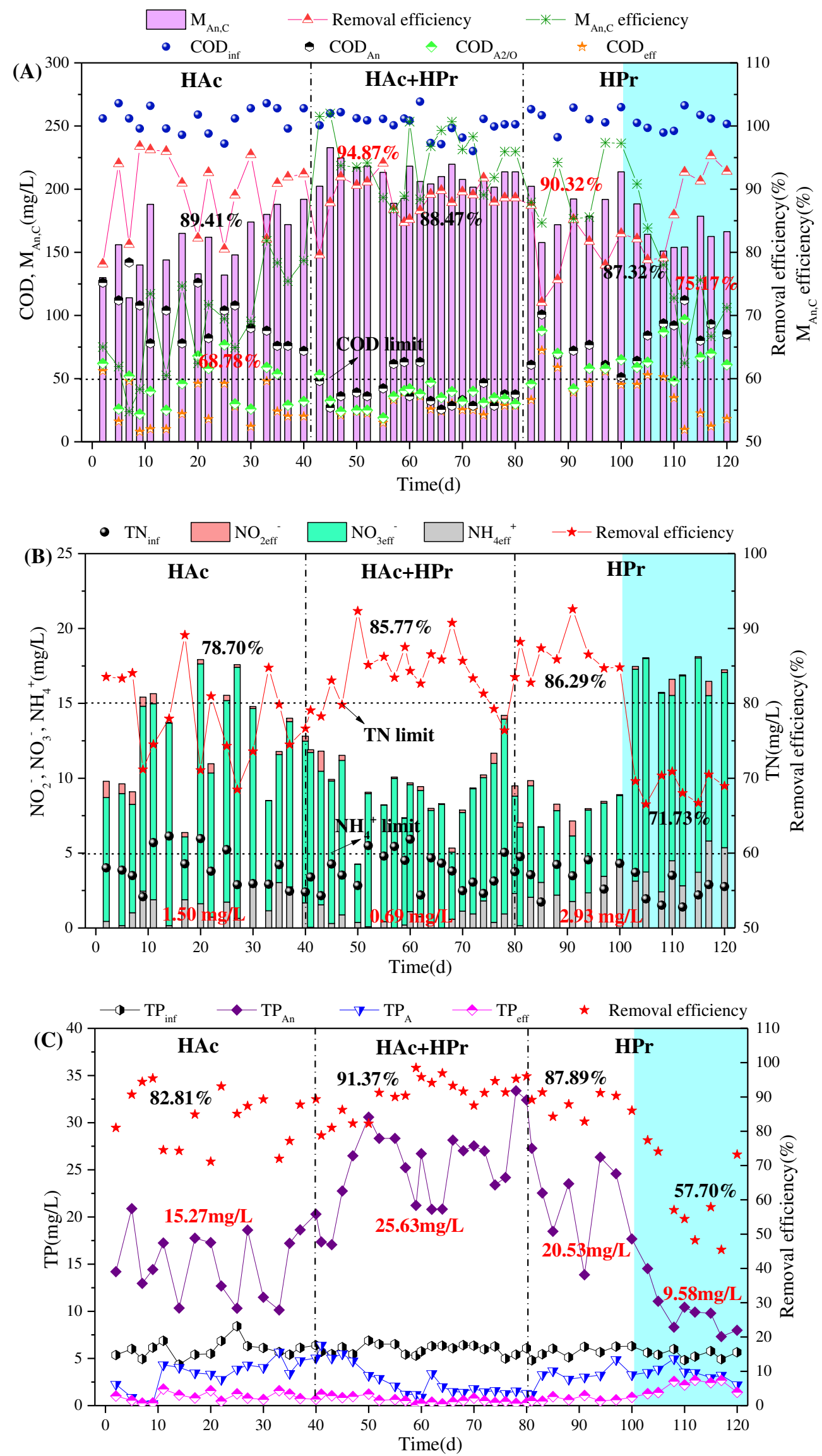

Fig.1 Profiles of nutrient removal in the $\mathrm{A}^{2} / \mathrm{O}-\mathrm{MBBR}$ system (A: COD; B: TN and $\mathrm{NH}_{4}^{+}$; C: TP) 

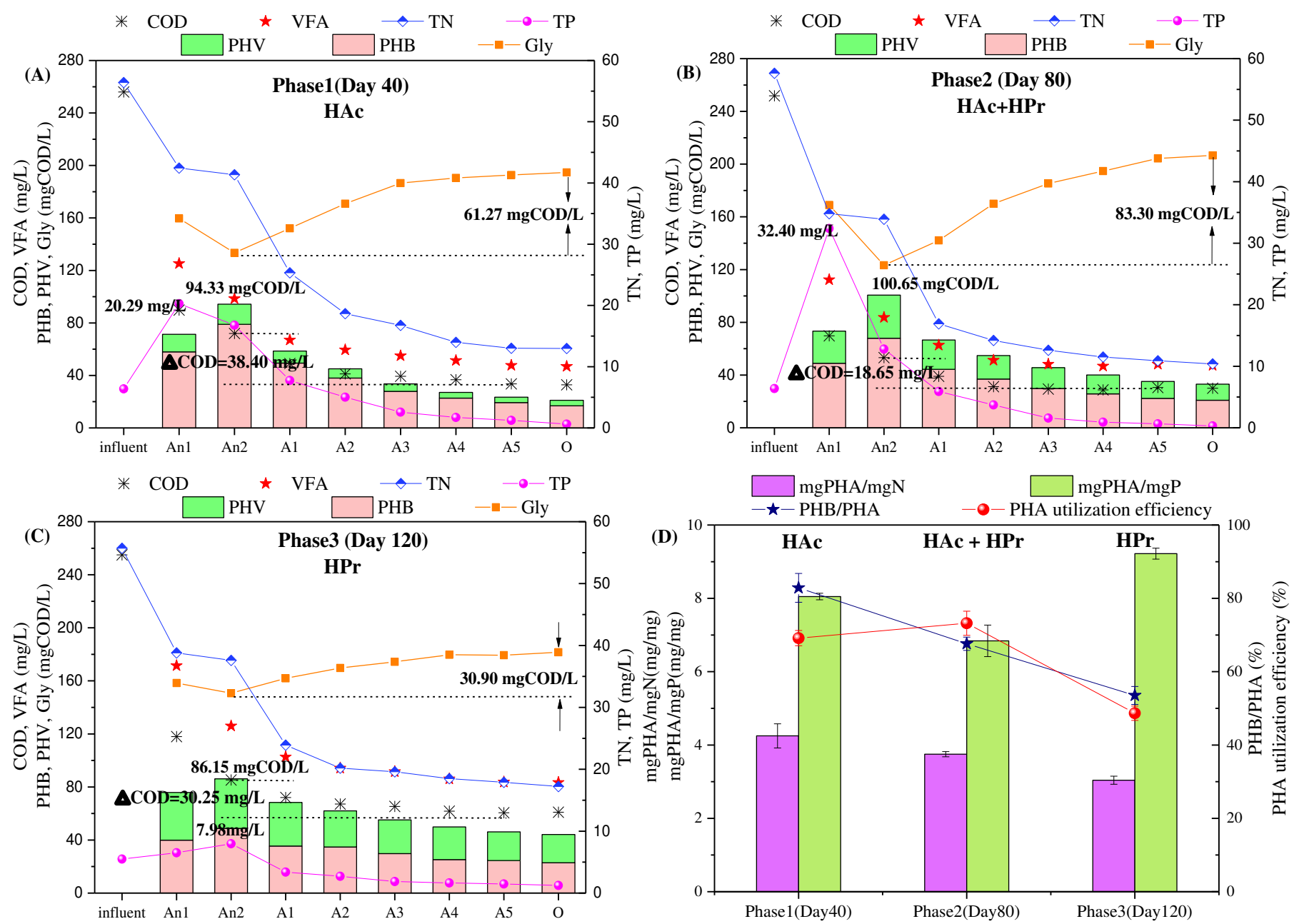

Fig.2 Nutrient evolution along the reaction zones (A, B, C) and PHA transformation and utilization (D) in the $\mathrm{A}^{2} / \mathrm{O}$ reactor 
Phase1 (Day 40)

HAc

(A)

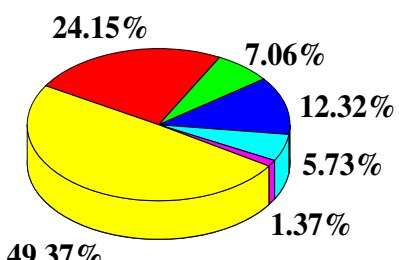

(B)

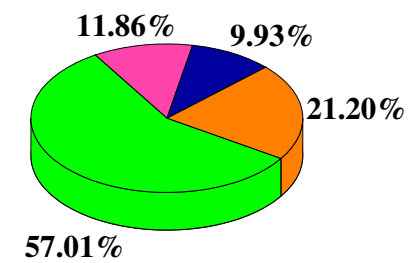

(C)

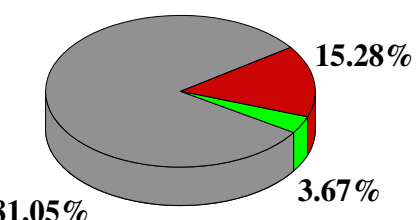

Phase2 (Day 80)

HAc + HPr

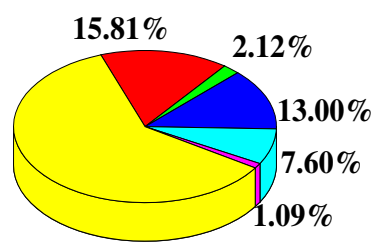

$60.38 \%$
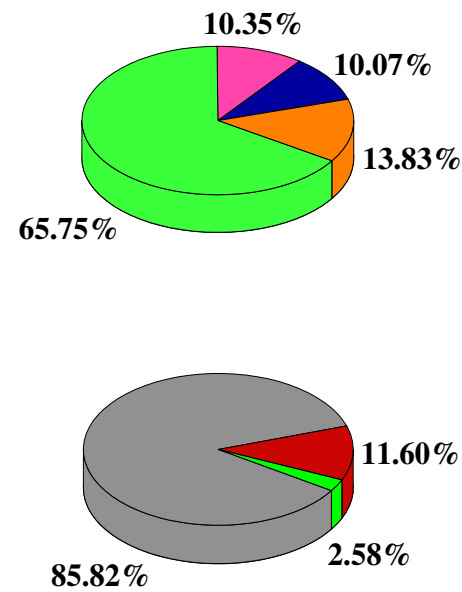

Phase3 (Day 120)

$\mathrm{HPr}$
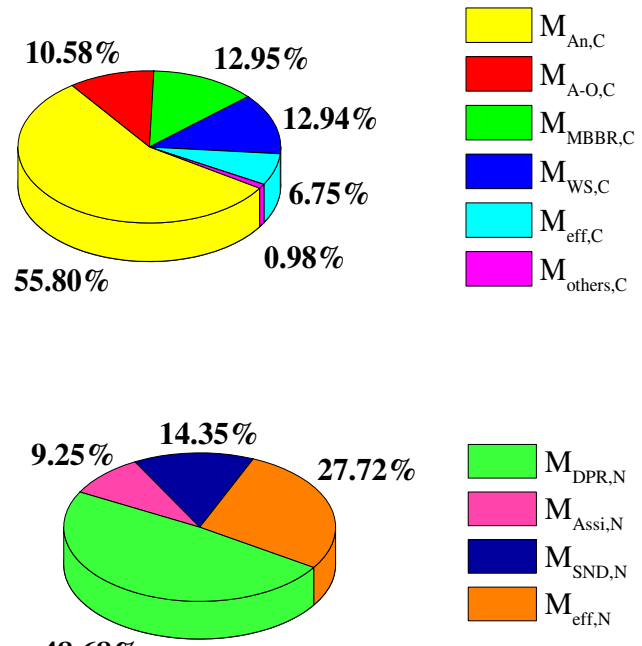

$48.68 \%$

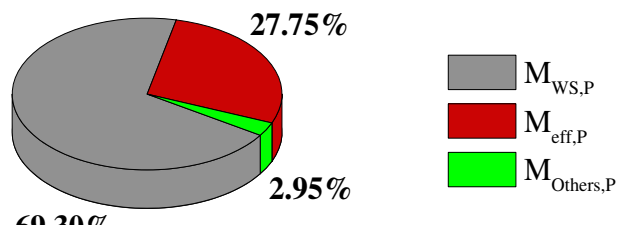

Fig.3 Mass balance analysis in the $\mathrm{A}^{2} / \mathrm{O}$ - MBBR system (A: Carbon; B: Nitrogen; C: Phosphorus) 
(A)

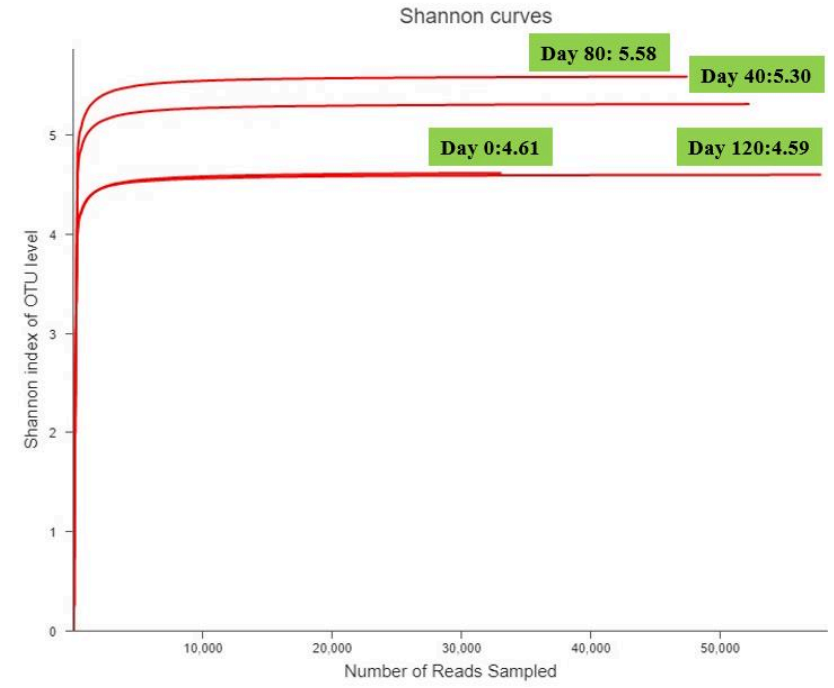

(B)

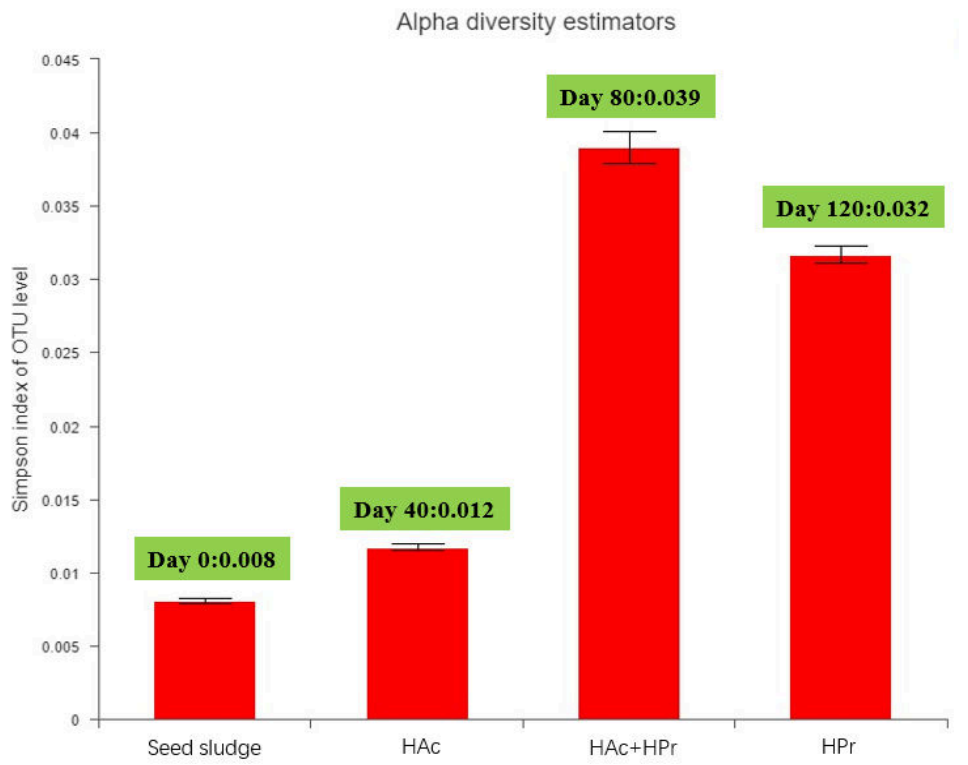

(C)

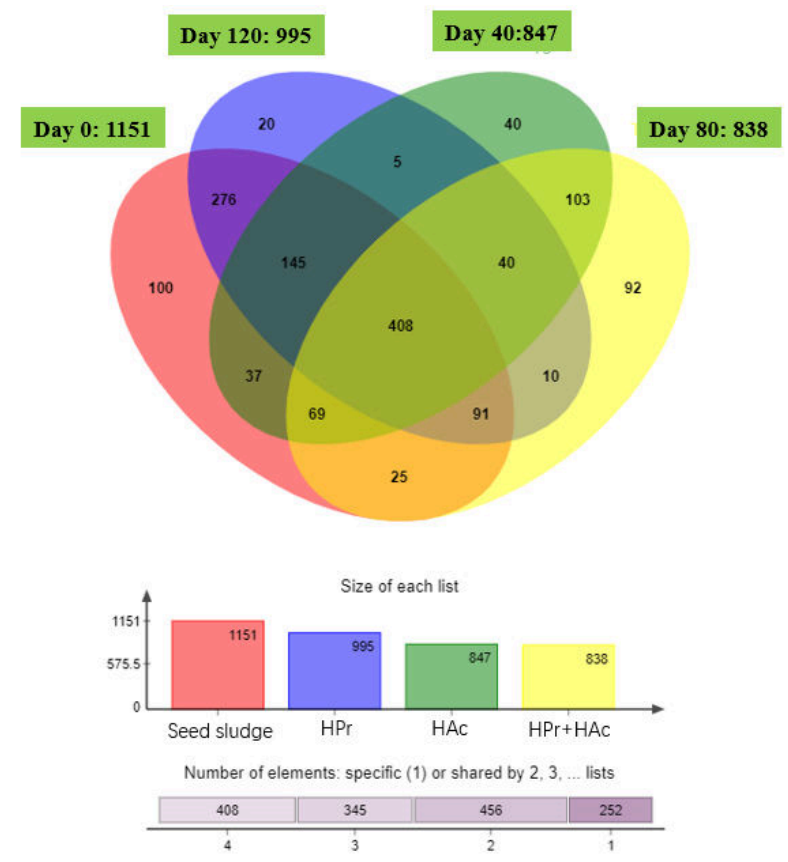

Fig.4 Bacterial biodiversity based on OTUs (A: Shannon index; B: Simpson index; C: Venn diagram) 


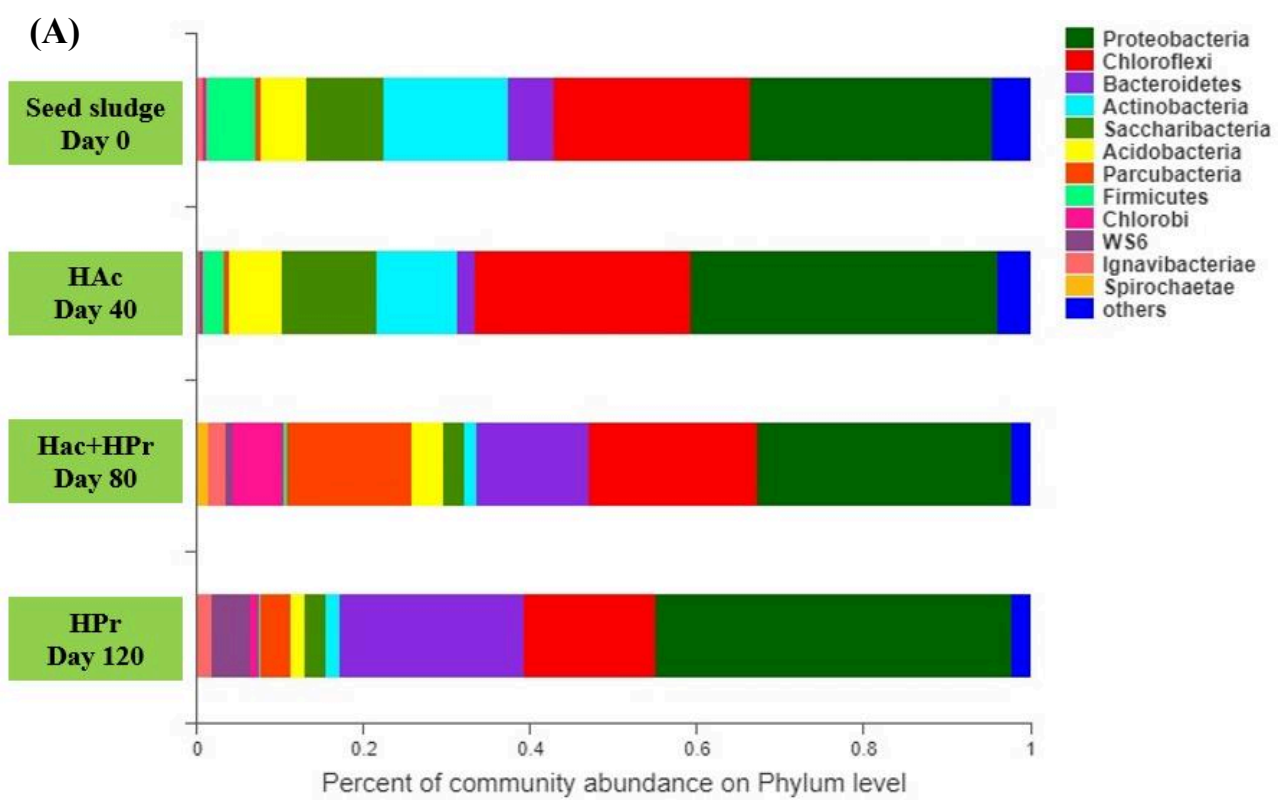

(B)

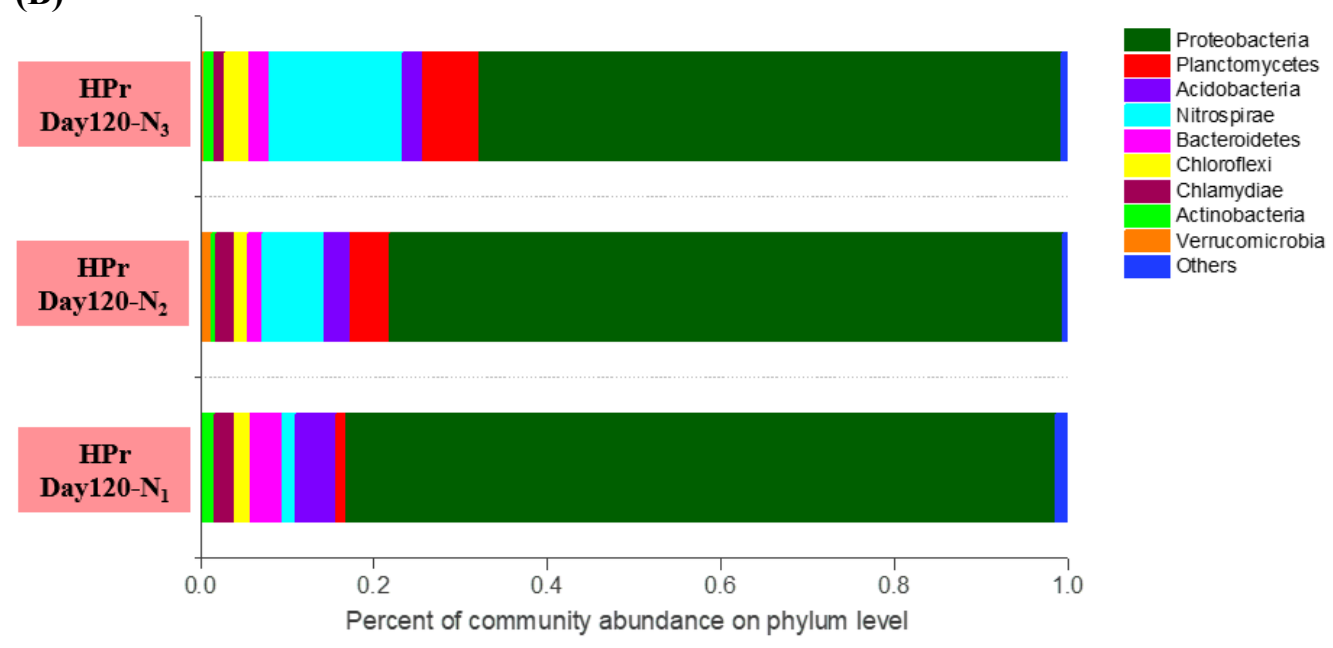

Fig.5 Microbial community structures of sludge (A) and biofilm (B) samples at phylum level 


\section{Highlights:}

1. It was feasible to strengthen DPR with the co-exist of acetate and propionate.

2. Carbon source revealed the strong relation with $\mathrm{M}_{\mathrm{An}, \mathrm{C}}$ efficiency and PHB/PHA ratio.

3. $40-45 \%$ carbon addition can be saved by the efficient utilization of carbon source.

4. Mass balance provided theoretical reference for the nutrient metabolic pathways.

5. Carbon source promoted the shift of species diversity and functional bacteria. 


\section{Graphical Abstract}
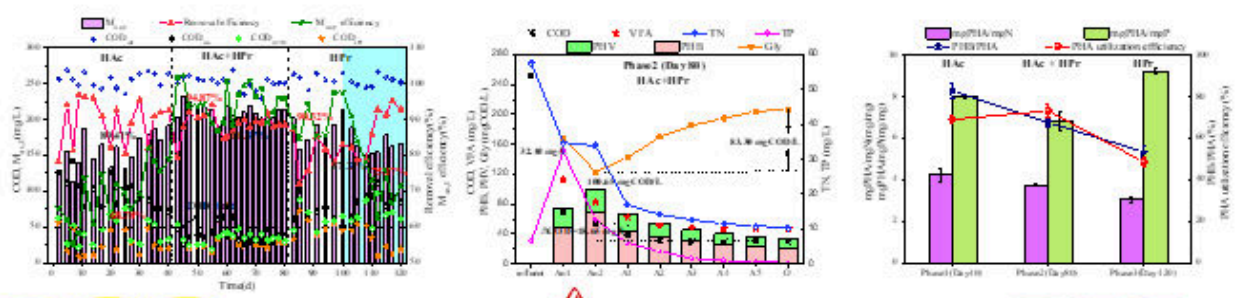

Removing $1 \mathrm{mg} \mathrm{NO} \mathrm{NO}_{3}$ $\left(\mathrm{PO}_{4}{ }^{3}\right.$ ) consumed 3.04 -

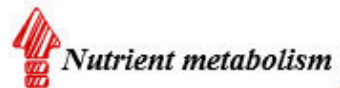

Saving $40-45 \%$

4.25 (6.84 - 9.82) mgPHA carbon source

\section{HAc $\mathrm{HAc}+\mathrm{HPr} \quad \mathrm{HPr}$}

Mass balance
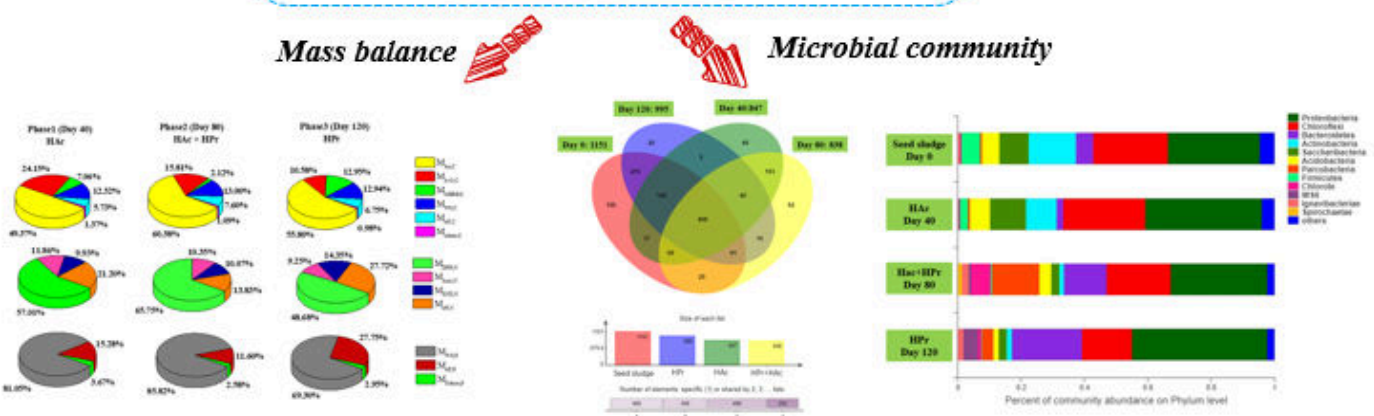


\section{Supporting Information:}

Nutrient metabolism, mass balance, and microbial structure community in a novel denitrifying phosphorus removal system based on the utilizing rules of acetate and propionate

Miao Zhang ${ }^{\mathrm{a}}$, Chenjie Zhu ${ }^{\mathrm{a}}$, Ting Pan ${ }^{\mathrm{a}}$, Yajun Fan ${ }^{\mathrm{b}}$, Ana Soares ${ }^{\mathrm{c}}$, Jun Wu ${ }^{\mathrm{a}}$, Chengda $\mathrm{He}^{\mathrm{a}}$

${ }^{a}$ College of Environmental Science and Engineering, Yangzhou University, Yangzhou 225127, PR China

${ }^{\mathrm{b}}$ Yangzhou Polytechnic Institute, Yangzhou 225127, PR China

${ }^{\mathrm{c}}$ Water Sciences Institute, Cranfield University, Cranfield, MK $430 A L, U K$

*Corresponding author. Tel.: +86 13905275314. E-mail: hcd@yzu.edu.cn (Ch. He)

Supporting information: 1 Figure.

Fig. S1 was used to point to Section 2.2. 


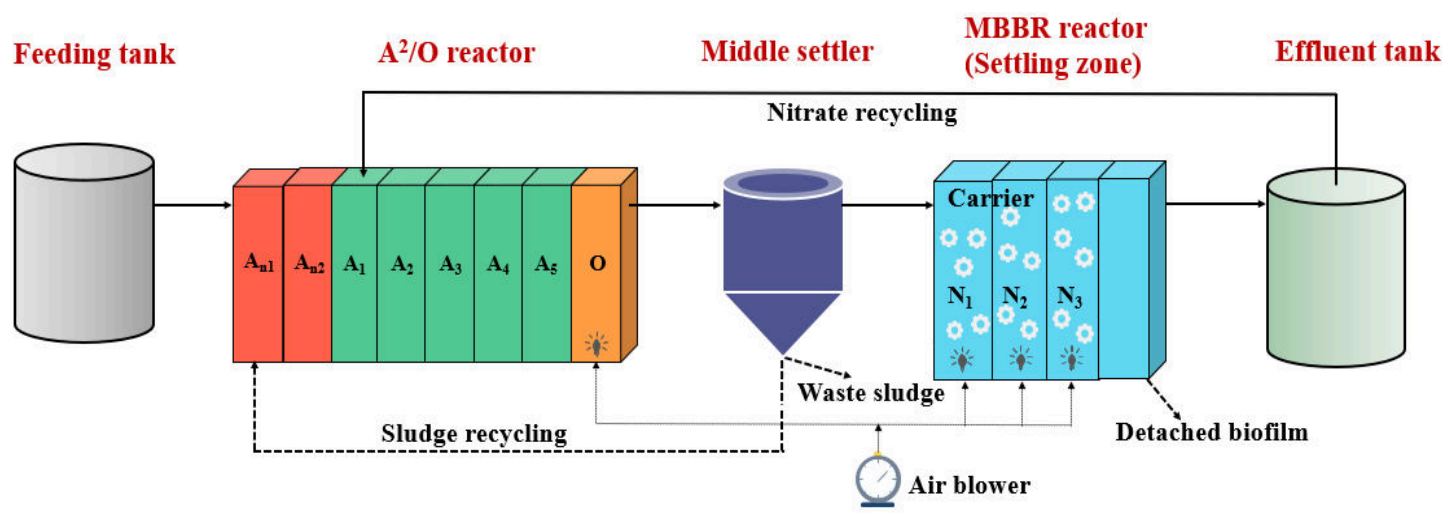

Fig.S1 Schematic diagram for the $A^{2} / O$ - MBBR system 